\title{
21. NORTHWEST PACIFIC SITE 882: THE INITIATION OF NORTHERN HEMISPHERE GLACIATION ${ }^{1}$
}

\author{
M.A. Maslin, ${ }^{2}$ G.H. Haug, ${ }^{2}$ M. Sarnthein, ${ }^{2}$ R. Tiedemann,${ }^{3}$ H. Erlenkeuser, ${ }^{4}$ and R. Stax ${ }^{5}$
}

\begin{abstract}
Ocean Drilling Program Site $882\left(50^{\circ} 22^{\prime} \mathrm{N}, 167^{\circ} 36^{\prime} \mathrm{E}\right)$ in the northwest Pacific is an excellent site to monitor changes in the surface- and deep-water circulation. Site 882 provides the first high-resolution GRAPE density, magnetic susceptibility, carbonate, opal, total organic carbon, and foraminifers (planktonic and benthic) stable isotope records between 3.2 and $2.4 \mathrm{Ma}$ in the North Pacific Ocean. We observe a dramatic increase in ice-rafting debris at Site 882 at $2.75 \mathrm{Ma}$, which is coeval with that found in the Norwegian Sea, suggesting that the Arctic and northeast Asia were significantly glaciated from $2.75 \mathrm{Ma}$ onward. At Site 882 this major change was accompanied by a dramatic drop in sea-surface temperatures $\left(>7.5^{\circ} \mathrm{C}\right)$ and opal mass accumulation rates (fivefold decrease), and is overlain by a more gradual long-term decrease in both total organic carbon and $\mathrm{CaCO}_{3} \mathrm{MARs}$. We suggest that the onset of Eurasian Arctic and northeast Asia glaciation is about $100 \mathrm{k} . \mathrm{y}$. before the glaciation of Alaska and $200 \mathrm{k} . \mathrm{y}$. before the glaciation of Greenland and the northeast American continent. We suggest that the initiation and intensification of Northern Hemisphere glaciation was forced by changes in the orbital parameters: in particular, the gradual increase in the amplitude of obliquity from 3.5 to $2.5 \mathrm{Ma}$ and a sharp rise in the amplitude of precession and thus insolation between 2.8 and $2.55 \mathrm{Ma}$.
\end{abstract}

\section{INTRODUCTION}

Ocean Drilling Program (ODP) Site 882 in the North Pacific Ocean is located at the northern end of the Emperor Seamount Chain, on the western flank of the Detroit Seamount $\left(50^{\circ} 22^{\prime} \mathrm{N}, 167^{\circ} 36^{\prime} \mathrm{E}\right)$ in a water depth of 3244 m (Rea, Basov, Janecek, Palmer-Julson, et al., 1993; Fig. 1). This site provides the first high-resolution carbonate, opal, total organic carbon (TOC), and foraminifer stable isotope records between 3.2 and $2.4 \mathrm{Ma}$ in the North Pacific. The sedimentation rate at this site varied between 3.2 and $2.4 \mathrm{Ma}$ from 12 to $4 \mathrm{~cm} / \mathrm{k}$.y., with a major drop in the sedimentation rate occurring at about $2.75 \mathrm{Ma}$ (Tiedemann and Haug, this volume). These sedimentation rates are sufficient, with the sampling density of $30 \mathrm{~cm}$, to depict the oceanographic variability in the range of Milankovitch orbital forcing. High-resolution proxy records of GRAPE density, magnetic susceptibility, $\mathrm{CaCO}_{3}$, and biogenic opal for the last $6 \mathrm{Ma}$ in conjunction with magnetostratigraphy (Rea, Basov, Janecek, Palmer-Julson, et al., 1993) have permitted an astronomical age calibration (Tiedemann and Haug, this volume) of the sediment record at Site 882 and the determination of fluxes. This age model has largely been confirmed by benthic and planktonic stable isotopes for both the first $750 \mathrm{ka}$ (Haug et al., this volume) and the period between 3.2 and $2.4 \mathrm{Ma}$ (this paper).

Modern oceanographic research has demonstrated that the northwest Pacific is the terminus of the deep-water salinity conveyer belt (Stommel, 1961; Broecker et al., 1985), where deep water diffuses upward to the surface (Craig et al., 1981; Broecker et al., 1988). This ascending deep water is highly enriched in nutrients (Craig et al., 1981 ) and thus stimulates high surface-water productivity (KoblentzMishke et al., 1970; Berger, 1989). Intermediate water formation in

\footnotetext{
${ }^{1}$ Rea, D.K., Basov, I.A., Scholl, D.W., and Allan, J.F. (Eds.), 1995. Proc. ODP, Sci, Results, 145: College Station, TX (Ocean Drilling Program).

${ }^{2}$ Geologisch-Paläontologisches Institut, Universităt Kiel, Olshausenstrasse 40, 24098 Kiel, Federal Republic of Germany.

${ }^{3}$ GEOMAR Forschungszentrum für Marine Geowissenschaften, Wischhofstrasse 1-3, 24148 Kiel, Federal Republic of Germany.

${ }^{4}$ C-14 Laboratory, Department of Physics, Universităt Kiel, 24098 Kiel, Federal Republic of Germany.

${ }^{5}$ Alfred Wegener Institut für Polarforschung, Columbusstrasse, 27568 Bremerhaven, Federal Republic of Germany.
}

the subarctic North Pacific is caused by the vertical mixing through the pycnocline, especially in regions with high precipitation (Reid, 1965) and this can enhance surface-water productivity by efficient mixing and recycling of nutrients. The formation of in situ intermediate waters in the North Pacific is also consistent with the known deeper circulation of the Pacific which involves upwelling in subarctic regions rather than overturn at intermediate depths (Reid, 1965; Moriyasu, 1972; Craig et al., 1981). Zahn et al. (1991a, 1991b), though, suggest that intermediate water in the North Pacific could be formed in the peripheral seas, that is, in the Sea of Japan and the Sea of Okhotsk.

Haug et al. (this volume) have shown that high $\mathrm{CaCO}_{3}$ accumulation rates for the last $2.6 \mathrm{Ma}$ at Site 882 have generally covaried with warm stages in the interglacial-glacial cycles. This pattern is similar to that found in the Atlantic (Olausson, 1965; Ruddiman, Sarnthein, et al., 1989), but is opposite to that found in most of the rest of the Pacific Ocean (Hebbeln et al., 1990; Farrell and Prell, 1991; Zahn et al., 1991b; Karlin et al., 1992). The Atlantic type pattern of $\mathrm{CaCO}_{3}$ accumulation in the northwest Pacific has also been observed by Hovan et al. (1991) and Keigwin et al. (1992). Haug et al. (this volume) suggested that during interglacial periods North Atlantic deepwater formation was strong and thus there was strong upward diffusion of nutrient-rich deep water in the northwest Pacific, at the terminus of the deep-water conveyer belt. This stimulated strong surface-water productivity, like today and was sufficiently large to overcome the strong dissolution of the highly corrosive Pacific deep waters, thereby allowing $\mathrm{CaCO}_{3}$ to accumulate. In contrast, the glacial periods had greatly reduced deep-water formation, and hence diminished upwelling and surface-water productivity, but increased carbonate aggressivity. Deep-water dissolution thus predominated; so there is little or no $\mathrm{CaCO}_{3}$ accumulation in the glacial periods. Haug et al. (this volume) have confirmed this hypothesis with highresolution opal, TOC, and foraminifer stable isotope records.

The work of Haug et al. (this volume) demonstrates that the northwest Pacific is extremely sensitive to changes in the deep-water flux. Site 882 thus provides an excellent location for monitoring deep-water and surface-water changes during the late Pliocene, especially the key period when Northern Hemisphere glaciation began at 3.1-2.6 Ma (Backman, 1979; Shackleton et al., 1984; Zimmerman et al., 1984; Sarnthein and Tiedemann, 1989; Tiedemann et al., 1994). 


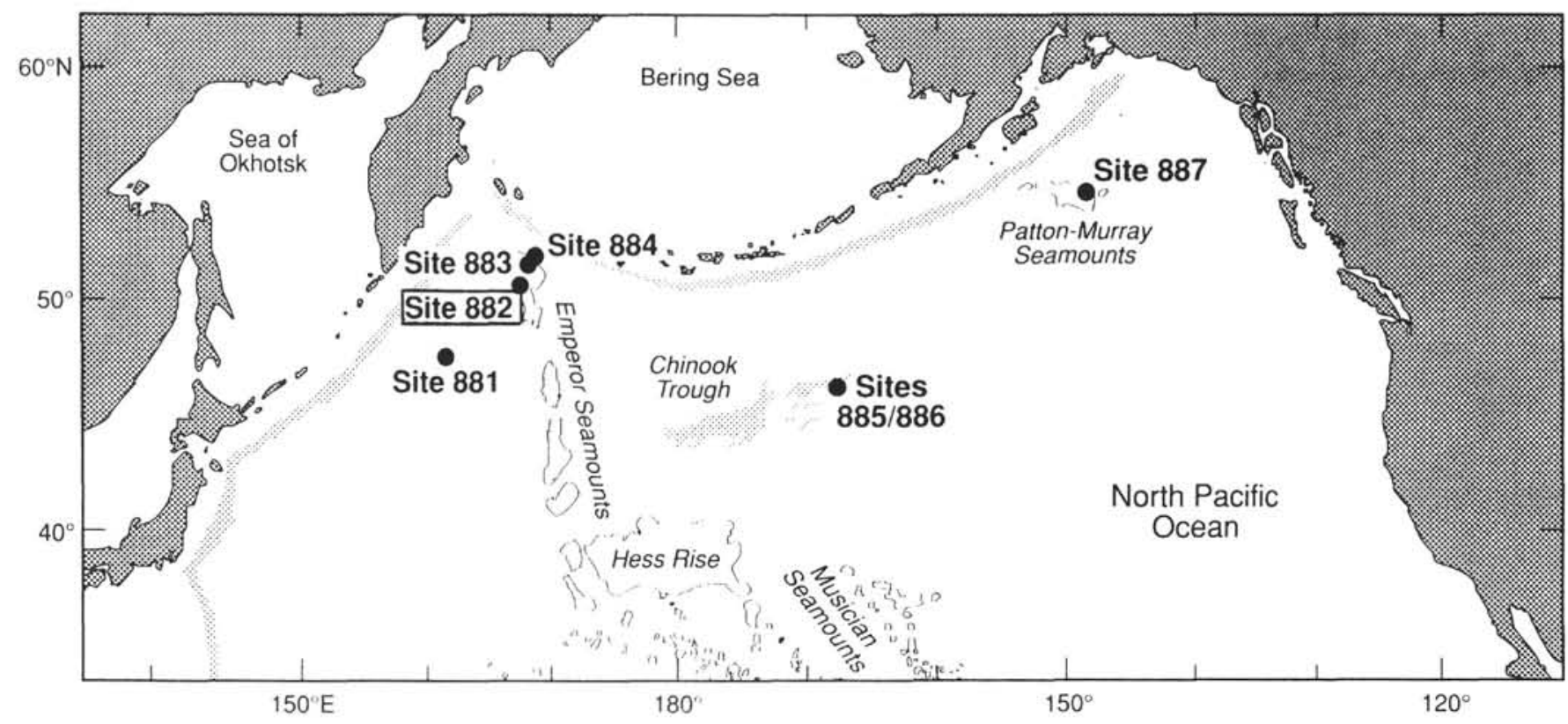

Figure 1. Location map for Site $882\left(50^{\circ} 21.79^{\prime} \mathrm{N}, 167^{\circ} 35.99^{\prime} \mathrm{E}\right)$ and the other Leg 145 sites.

\section{OBSERVATIONS AND THEORIES ABOUT THE INITIATION OF NORTHERN HEMISPHERE GLACIATION}

The glaciation of Greenland and the Arctic is believed to have begun in the late Miocene (Leg 151 Scientific Party, 1994). There is also strong evidence for the formation of sea ice and snow cover in the Arctic and subarctic regions in the late Miocene-early Pliocene (Jansen et al., 1990; Jansen and Sjøholm, 1991). The first occurrence, however, of significant ice sheets in the Northern Hemisphere was according to Shackleton et al., (1984) at $2.55 \mathrm{Ma}$ (using the new time scale of Shackleton et al., 1990; and Hilgen, 1991), although proceeded by smaller increases in ice volume from $2.7 \mathrm{Ma}$ (Backman, 1979; Shackleton et al., 1984; Zimmerman et al., 1984). These conclusions were based primarily on relative coarse resolution records of $\% \mathrm{CaCO}_{3}$ and $\delta^{18} \mathrm{O}$ records from Deep Sea Drilling Project (DSDP) Site 552 in the Atlantic Ocean (Shackleton et al., 1984). The drop in $\% \mathrm{CaCO}_{3}$ was explained by an increase in ice-rafted debris coeval with the drop in $\delta^{18} \mathrm{O}$ that indicates an increase in global ice volume (Shackleton et al., 1984). It has though been shown that significant glaciation of the Arctic, Northern Scandinavia (Jansen et al., 1990; Jansen and Sjøholm, 1991) and Iceland (Einarsson and Albertsson, 1988) occurred as early as $3 \mathrm{Ma}$. Jansen et al. (1990) and Jansen and Sjøholm (1991) showed from measurements of ice-rafted debris at ODP Holes 642B and 644A in the Norwegian Sea that there was an initial increase in the flux of icebergs at $3 \mathrm{Ma}$ and a dramatic rise at $2.75 \mathrm{Ma}$, suggesting the Arctic was ice covered at least 200 k.y. before the eastern American continent.

Recent evidence, though, suggests that the initiation of major Northern Hemisphere glaciation was the culmination of a longer term high-latitude cooling that began at 3.2 Ma (Ruddiman et al., 1986, Tiedemann et al., 1994). Progressive and oscillatory enrichment of benthic foraminifer $\delta^{18} \mathrm{O}$ suggests that there was significant deepwater cooling and an increase in global ice volume after 3.2 Ma (Prell, 1984; Hodell et al., 1991; Keigwin, 1987; Ruddiman et al., 1986; Sarnthein and Tiedemann, 1989; Tiedemann et al., 1994).

There is strong evidence for this progressive cooling of the Northern Hemisphere from the increase in the percentage of cooler living planktonic foraminifer (Loubere and Moss, 1986; Raymo et al., 1987) and by decreasing discoaster abundances (Backman and Pestiaux,
1986). Sea-surface temperatures, however, at this time interval are not easily reconstructed, as the assemblages are not completely analogous to modern faunas (Ruddiman and Raymo, 1988).

The most recent benthic foraminifer $\delta^{18} \mathrm{O}$ results from Site 659 in the tropical east Atlantic (Tiedemann et al., 1994) and Site 846 in the equatorial east Pacific (Shackleton et al., in press) show a gradual enrichment of ${ }^{18} \mathrm{O}$ of the ocean between 3.2 and $2.75 \mathrm{Ma}$. From 2.75 to $2.68 \mathrm{Ma}$, there are three periods with very heavy $\delta^{18} \mathrm{O}$ values, with minimal recovery in between. Subsequently, there were still further increases in the average $\delta^{18} \mathrm{O}$ value and a marked increase in the amplitude variation between warm and colder periods. The major controversy at present is how much of these $\delta^{18} \mathrm{O}$ decreases represent cooling of the deep waters and how much represents the first accumulation of ice in the Northern Hemisphere. The three major decreases in benthic $\delta^{18} \mathrm{O}$ between 2.75 and $2.68 \mathrm{Ma}$, it is believed, were primarily because of a significant increase in global ice volume (Shackleton et al., in press; Tiedemann et al., 1994).

Sarnthein and Tiedemann (1989) and Raymo et al. (1992) demonstrated from the benthic $\delta^{13} \mathrm{C}$ and $\delta^{18} \mathrm{O}$ of a number of ODP cores in both the Atlantic and Pacific oceans, that the gradual global cooling between 3 and $2 \mathrm{Ma}$ was associated with an increased suppression of the formation of the North Atlantic Deep Water (NADW). They also suggested that the relative strength of NADW production during the late Pliocene was always greater than that observed from the late Pleistocene glaciations. High-resolution benthic isotopic data of Shackleton et al. (in press) and Tiedemann (pers. comm., 1994) from the tropical Pacific and Atlantic demonstrate an in-phase relationship between $\delta^{18} \mathrm{O}$ and $\delta^{13} \mathrm{C}$ during the Pliocene, so during the colder periods of the Pliocene there is a marked increase in the suppression of deep-water formation.

The North Pacific Site 882 GRAPE density and magnetic susceptibility records show a dramatic increase at $2.75 \mathrm{Ma}$. Coeval with this change are marked variations in biogenic opal, carbonate, TOC, and planktonic isotopes, which are discussed in this paper.

Several explanations have been put forward to explain the initiation of Northern Hemisphere glaciation. One group of theories suggests changes in atmospheric composition (i.e., $\mathrm{CO}_{2}$ ) or a change in total solar radiation. Suggestions such as changes in solar radiation are not testable (Opik, 1959), whereas changes in atmospheric $\mathrm{CO}_{2}$ content could be detected in the geological record (Sarnthein and Fenner, 
1988). Increased volcanism during the latest Cenozoic (Kennett and Thunell, 1975) has also been suggested as a possible cause of glaciation. Other theories include virtual polar wander (Ewing and Donn, 1956; Schneider and Kent, 1986), uplift of the highlands of northern Canada (Flint, 1957; Emiliani and Geiss, 1958; Birchfield et al., 1982), and changes in land-sea distribution by seafloor spreading (North et al., 1983). These theories are either too negligible in effect or too long-term to have caused the sudden initiation of Northern Hemisphere glaciation.

Tectonic explanations have also been suggested, such as the emergence of the Panama Isthmus (Keigwin, 1978, 1982; Keller et al., 1989; Mann and Corrigan, 1990) and the deepening of the Bering Straits (Einarsson et al., 1967). The most recent dating of the closure of the Pacific-Caribbean gateway (Keller et al., 1989) suggests that the Panama Isthmus began to emerge gradually at $6.2 \mathrm{Ma}$ and finally closed at 1.8 Ma. Keller et al. (1989) also documented four major events in the progressive closure of the Pacific-Caribbean gateway: 6.2 Ma, 4.2 Ma, 2.4 Ma (2.55 Ma with new time scale), and 1.8 Ma. Keller et al. (1989) showed that there was an increasing abundance of salinity-tolerant planktonic foraminifers in the Caribbean from 2.55 $\mathrm{Ma}$ onward, suggesting the restriction of water flow between the Pacific and Caribbean started at $2.55 \mathrm{Ma}$ and ceased completely at 1.8 Ma. However, progressive and gradual closure from 2.55 Ma onward is too late to have been the cause of the intensification of Northern Hemisphere glaciation. The reduced outflow of Caribbean surface water to the Pacific increased the salinity of the Caribbean. This would have both increased the salinity and strength of the Gulf Stream, thus enhanced deep-water formation (Mikolajewicz et al., 1993). Increased deep-water formation could have worked against the initiation of Northern Hemisphere glaciation as greater heat transport to the high latitudes would have tended to prevent ice sheet formation. A contrasting argument is that the enhanced Gulf Stream could have pumped moisture north, stimulating the formation of ice sheets (Mikolajewicz et al., 1993). If the closure of the Panama gateway did increased the strength of the Gulf Stream, this should have in turn increased deep-water ventilation. However, the benthic $\delta^{13} \mathrm{C}$ record from Site 659 over the last $5 \mathrm{Ma}$ (Tiedemann, 1991), does not show any long-term increase in the $\delta^{13} \mathrm{C}$ between 3.5 and $2.0 \mathrm{Ma}$ nor a steplike increase at around $2.55 \mathrm{Ma}$ that might occur with a more abrupt closure of the Panama gateway. Moreover, comparison with the global benthic isotope records (Shackleton et al., in press; Tiedemann et al., 1994) shows there is a strong warm period with a suppressed cool period at 2.6-2.5 Ma, which suggests that this period of Panama Isthmus formation did not enhance the glaciation of the Northern Hemisphere.

The tectonic changes of the Bering Sea were initially dated between 3.5 and $3 \mathrm{Ma}$ (Einarsson et al., 1967), and more recently the submergence of the Bering Strait has been dated as 3.2 Ma (Fyles et al., 1991), which is too early to have caused the dramatic changes near $2.7 \mathrm{Ma}$, but they may have indeed contributed to the long-term global cooling that started at about $3.2 \mathrm{Ma}$.

Ruddiman and Raymo (1988), Ruddiman et al. (1989), and Ruddiman and Kutzbach (1991) discuss how the initiation of Northern Hemisphere glaciation could have been caused by progressive uplift of the Tibetan-Himalayan and Sierran-Coloradan regions. They suggest that this uplift altered the circulation of the atmospheric planetary waves such that ablation was decreased, which allowed snow and ice to build up in the Northern Hemisphere. Discussion continues as to whether orography (Charney and Eliasson, 1949; Bolin, 1950), differential heating of land and sea surfaces (Sutcliffe, 1951; Smagorinsky, 1953), or a combination of both (Trenberth, 1983) control the structure and direction of the planetary waves. In contrast, Copeland et al. (1987) and Molnar and England (1990) have suggested that majority of the Himalayan uplift occurred much earlier, between $20 \mathrm{Ma}$ and $17 \mathrm{Ma}$. Harrison et al. (1992), from thermochronologic results, have suggested the Tibetan Plateau reached its maximum elevation during the late Miocene at about 7-8 $\mathrm{Ma}$ and not during the mid-Pliocene as sug- gested by paleobotanic studies (Mercier et al., 1987). Quade et al. (1989) also showed from carbon and oxygen isotopes of a pedogenic sediment profile in Pakistan that the Asian monsoons underwent a strong intensification at 7.4 Ma, which they present as further evidence of a late Miocene uplift, thus invalidating Ruddiman and Raymo's (1988) hypothesis.

In conclusion, the causes of the long-term global cooling that started at 3.2 Ma and the significant increase in Northern Hemisphere glaciation near $2.75 \mathrm{Ma}$ are essentially unresolved. Here we suggest that changes in orbital forcing may have been an important mechanism controlling the gradual global cooling and the subsequent intensification of Northern Hemisphere glaciation.

\section{METHODS}

The $\mathrm{CaCO}_{3}$ contents were determined by coulometric technique using a Coulomat 702 at the University of Kiel. Furthermore, the carbonate record includes about 140 shipboard-measured values that were determined by the same technique. The accuracy was better than $1.5 \%$, as obtained by replicate carbonate standard measurements. The TOC method is given in Stax and Stein (this volume).

The biogenic opal content was separated from the siliciclastic fraction in the carbonate-free fraction $>2 \mu \mathrm{m}$ by the density separation technique (Bohrmann et al., 1990), using sodium-polywolframate as the heavy-liquid solution. The carbonate-free clay fraction was separated by means of the Atterberg separation method (Müller, 1967).

Mass accumulation rates $\left(\mathrm{g} / \mathrm{cm}^{2} / \mathrm{k}\right.$. y. $)$ were calculated as the product of sedimentation rates ( $\mathrm{cm} / \mathrm{k} . \mathrm{y}$.$) , percentages of the individual$ compounds, and dry-bulk density values $\left(\mathrm{g} / \mathrm{cm}^{3}\right.$; Rea, Basov, Janecek, Palmer-Julson, et al., 1993). Mean sedimentation rates were linearly interpolated between age control points (Tiedemann and Haug, this volume). Dry-bulk density values were derived from the GRAPE wetbulk-density analog data empirically using the following equation:

$$
\begin{gathered}
\text { Dry-bulk density }=1.67 \cdot \text { density GRAPE }-1.89 \\
(r=0.83 ; n=112) .
\end{gathered}
$$

This equation is based on in situ dry-bulk density data from various depth sections throughout Hole $882 \mathrm{~A}$. The estimated dry-bulk density data reproduce the measured in situ data to within a standard error of $0.2 \mathrm{~g} / \mathrm{cm}^{3}$. With the use of accumulation rates, percentage dilution effects by different sediment components can be removed from the particle record under inspection.

The $\delta^{18} \mathrm{O}$ and $\delta^{13} \mathrm{C}$ of the benthic and planktonic foraminifers were measured according to the standard techniques at the University of Kiel. The samples were freeze dried and then wet sieved through a $63-\mu \mathrm{m}$ mesh sieve. The samples were then dry sieved at convenient intervals between 250 and $400 \mu \mathrm{m}$, from which the foraminifers were picked. Two benthic species were selected for analysis: $C$. wuellerstorfi and Uvigerina sp. In many cases in which the lack of $\mathrm{CaCO}_{3}$ resulted in the measurement of only one specimen, the gas pressure from the mass spectrometer was checked to be sure there was sufficient material for a reliable estimate. Three planktonic foraminifer species were analyzed, G. bulloides, $N$. pachyderma (R), and $N$. pachyderma (L). G. bulloides and N. pachyderma (R) occurred with a sufficient time resolution to have near-continuous records between 3.4 and $2.4 \mathrm{Ma}$, whereas $N$. pachyderma (L) occurred sporadically and was used only to confirm the pattern of the other two species. The number of each species found at each sample depth varied greatly because of the fluctuation in $\mathrm{CaCO}_{3}$ accumulation; in the cases with low numbers of specimens (no sample of less than 6 specimens was measured), the gas pressure from the mass spectrometer was noted to make sure there was sufficient material for a reliable estimate. It should be noted that both variations in the number of planktonic foraminifers per sample and a low number of specimens per sample can be major causes for errors (M. Maslin and M. Hall, unpubl. data, 1994). At sedimentation rates exceeding $10 \mathrm{~cm} / \mathrm{k} . \mathrm{y}$, which do occur 
at Site 882 (Tiedemann and Haug, this volume), however, the bioturbation component of these errors is reduced. These possible errors were considered when the isotope records were interpreted.

To obtain complete and continuous proxy records for the last 4.0 $\mathrm{Ma}$, we adjusted the value measured at each sampling depth to the composite depth record of Holes $882 \mathrm{~A}$ and $882 \mathrm{~B}$. The two records were spliced using correlations between the magnetic susceptibility and GRAPE records of Holes $882 \mathrm{~A}$ and $882 \mathrm{~B}$. This composite depth scale was developed only for the upper $255.95 \mathrm{~m}$ (Hole 882A), which is equivalent to a composite depth of $287.78 \mathrm{mbsf}$. Below this the composite depth section remains uncertain because of only short overlapping sections between Holes $882 \mathrm{~A}$ and $882 \mathrm{~B}$, which ends at 270.4 mbsf (Rea, Basov, Janecek, Palmer-Julson, et al., 1993).

All data are summaries in the Appendix, Tiedemann et al. (this volume), and Haug et al. (this volume). The data are also available on request from the German PAGES Marine Paleodata Bank (A.W.I. Bremerhaven).

\section{AGE MODEL}

The time scale at Site 882 was based initially on magnetostratigraphy. The ages for the magnetic reversal boundaries were derived from the orbitally tuned time scale of Shackleton et al. (1990), Shackleton et al. (in press), and Tiedemann et al. (1994), which improved on Hilgen (1991). Using the astronomically dated magnetic reversals for initial age control, as expected the fluctuations in the GRAPE-density and magnetic susceptibility records were linked to variations in the Earth's orbit. Tiedemann and Haug (this volume) generated an astronomically calibrated stratigraphy for the last $4 \mathrm{Ma}$ based on fine-tuning the GRAPE density oscillations in the precession band to the summer insolation at $65^{\circ} \mathrm{N}$ (Berger and Loutre, 1991). This calibration was based on the assumption that GRAPE-density maxima are linked to minima in biogenic opal and maxima in ice-rafted debris and hence to glacial stages (insolation minima) during the last $2.75 \mathrm{Ma}$. Prior to $2.75 \mathrm{Ma}$ the relationship between the GRAPE density and climate was reversed, which is confirmed by the benthic $\delta^{18} \mathrm{O}$ results from Site 882. Adetailed description of the astronomical calibrated age model is given by Tiedemann and Haug (this volume).

Sedimentation rates were linearly interpolated between the age control points given in Tiedemann and Haug (this volume).

\section{RESULTS}

In general, mass accumulation rates of $\mathrm{CaCO}_{3}$, opal, and TOC have a pattern similar to their weight percentages. The following description uses mass accumulation rates (MAR) of $\mathrm{CaCO}_{3}$, opal, and TOC, as this more representative of the actual flux and is not subject to percentage dilution (Fig. 2). The carbonate accumulation at Site 882 for the last $5.9 \mathrm{Ma}$ varies between 0 and $3 \mathrm{~g} / \mathrm{cm}^{2} / \mathrm{k}$.y. There are major cyclic variations in amplitude, and many intervals have no carbonate preserved. In general, Pleistocene interglacial periods and Pliocene warm stages show good carbonate preservation, which is comparable to the pattern of carbonate preservation in the Atlantic (Haug et al., this volume).

During the key period 3.2-2.4 Ma (Fig. 2-4), there were large changes in the MAR of calcium carbonate. Between 3.2 and 2.82 Ma the carbonate MAR varies cyclically at approximately $41 \mathrm{ka}$ (Tiedemann and Haug, this volume), between high accumulation rates (up to $4 \mathrm{~g} / \mathrm{cm}^{2} / \mathrm{k}$.y.) and periods of very low or no accumulation. The size of these variations decreases gradually to $2.82 \mathrm{Ma}$; subsequently there was very little or no $\mathrm{CaCO}_{3}$ accumulation for approximately $500 \mathrm{ka}$. This decrease in $\mathrm{CaCO}_{3}$ MAR parallels the gradual global cooling indicated by the benthic $\delta^{18} \mathrm{O}$ (Shackleton et al., in press; Tiedemann et al., 1994). Comparison of the $\mathrm{CaCO}_{3} \mathrm{MAR}$ peaks of Site 882 with the benthic $\delta^{18} \mathrm{O}$ from Site 846 indicates that they mostly occur during warm periods of the preglacial Pliocene (Fig. 4). The only $\mathrm{CaCO}_{3}$ MAR peaks which seem to be partially out of phase with the global benthic $\delta^{18} \mathrm{O}$ and $\delta^{13} \mathrm{C}$ of Site 846 (Shackleton et al., in press; Tiedemann et al., 1994) are at 2.91 and $2.97 \mathrm{Ma}$. If the $\mathrm{CaCO}_{3}$ MAR record is compared with the Site 882 stable isotope records of $C$. wuellerstorfi, then the peaks correlate to light $\delta^{18} \mathrm{O}$ and heavy $\delta^{13} \mathrm{C}$ values. This suggests that the $\mathrm{CaCO}_{3}$ MAR peaks at 2.91 and $2.97 \mathrm{Ma}$ actually do occur during warmer periods, and that there are minor offsets in the tuned age model. The occurrence of peaks in carbonate preservation during warm periods with heavy benthic $\delta^{13} \mathrm{C}$ supports the link proposed by Haug et al. (this volume) between enhanced Atlantic deep-water formation and $\mathrm{CaCO}_{3}$ accumulation in the Pliocene. Between 2.72 and $2.65 \mathrm{Ma}$ the carbonate accumulation weakly increases to $0.4 \mathrm{~g} / \mathrm{cm}^{2} / \mathrm{k}$.y.; subsequently there are only a few scattered smaller peaks until $1.7 \mathrm{Ma}$, when the interglacial-glacial cyclicity seems to exert itself (Haug et al., this volume).

Despite the lack of $\mathrm{CaCO}_{3}$ in large sections of the core, both benthic and planktonic foraminifer stable isotopes were obtained for Site 882 between 3.1 and $2.5 \mathrm{Ma}$. The isotope records of $N$. pachyderma $(\mathrm{R})$ and $G$. bulloides are the most complete and have a high degree of similarity in both their oxygen and carbon records. These records are in parts confirmed by the data from $N$. pachyderma (L), suggesting that these are a true record of the surface-water conditions of the northwest Pacific and not an individual species effect. The benthic record of both Uvigerina sp. and $C$. wuellerstorfi are less complete and more noisy but indicate a variation of between $1 \%$ to $2 \%$ between 3.1 and $2.5 \mathrm{Ma}$.

The planktonic $\delta^{18} \mathrm{O}$ records indicates cyclic but very light values culminating near $2.75 \mathrm{Ma}$. At $2.75 \mathrm{Ma}$ there is a drop of at least $2.6 \%$, indicated by all three species, to much heavier values. This is presumably due to a massive drop in sea-surface temperature as at about 2.75 $\mathrm{Ma}$; the GRAPE density and magnetic susceptibility indicate a significant increase in ice-rafted debris and thus iceberg flux to Site 882 . The planktonic foraminifer $\delta^{13} \mathrm{C}$ records also show a high degree of similarity with the $\mathrm{CaCO}_{3}$ MAR record (Fig. 2). Heavier planktonic $\delta^{13} \mathrm{C}$ values are associated with preservation peaks in $\mathrm{CaCO}_{3}$. This may support the idea that the $\mathrm{CaCO}_{3} \mathrm{MAR}$ is primarily an indicator of surface-water productivity (Haug et al., this volume); if the increases in productivity, which preferentially remove ${ }^{12} \mathrm{C}$, are indeed recorded by the planktonic foraminifers.

Biogenic opal MARs were continuously high (3-6 g/cm $2 / \mathrm{k}$.y.) from before 3.2 to $2.725 \mathrm{Ma}$. There is a drop in both the opal MAR and TOC MAR at $2.91 \mathrm{Ma}$, from an average value of $5 \mathrm{~g} / \mathrm{cm}^{2} / \mathrm{k}$.y. to $3 \mathrm{~g} / \mathrm{cm}^{2} / \mathrm{k}$.y. This could be an artifact of the age model, as this drop is not seen in the weight percentage records (Haug et al., this volume). There is an irreversible drop (by approximately a factor of 5) in both the opal MAR and weight percentage records between 2.740 and $2.725 \mathrm{Ma}$, and this causes the dramatic drop in sedimentation rates from 13 to $4 \mathrm{~cm} / \mathrm{k}$.y. observed at about $2.75 \mathrm{Ma}$ (Tiedemann and Haug, this volume). This is followed by very low opal MAR values $\left(\mathrm{g} / \mathrm{cm}^{2} / \mathrm{k}\right.$.y.) until $2.4 \mathrm{Ma}$. Between 2.4 and $2.25 \mathrm{Ma}$ there are some minor cyclic peaks in the opal MAR up to $1 \mathrm{~g} / \mathrm{cm}^{2} / \mathrm{k}$.y. From 2.25 to 1.6 Ma there is little or no opal accumulation. Low but distinct interglacial-to-glacial cycles $\left(0.1-1.5 \mathrm{~g} / \mathrm{cm}^{2} / \mathrm{k}\right.$.y.) occur from $1.6 \mathrm{Ma}$ to the present, with high opal values linked to interglacial periods (Haug et al., this volume).

The TOC values for Site 882 and the other sites from Leg 145 (Stax and Stein, this volume) are very low. Between 3.25 and $2.65 \mathrm{Ma}$ there is a gradual sawtoothed decline in the TOC from an average of $0.025 \mathrm{~g} / \mathrm{cm}^{2} / \mathrm{k}$.y. to $0.015 \mathrm{~g} / \mathrm{cm}^{2} / \mathrm{k}$.y., but with significant spikes at 2.79 and $2.73 \mathrm{Ma}$ (maximum $0.29 \mathrm{~g} / \mathrm{cm}^{2} / \mathrm{k}$.y.). Subsequently there are lower TOC MAR values than the preglacial Pliocene, interrupted only by peaks at 2.63 and $2.53 \mathrm{Ma}$.

\section{DISCUSSION}

\section{Opal and TOC MAR Variations at Site 882}

The major change in the paleoceanography of the northwest $\mathrm{Pa}$ cific culminated around $2.75 \mathrm{Ma}$, when there was a dramatic increase 

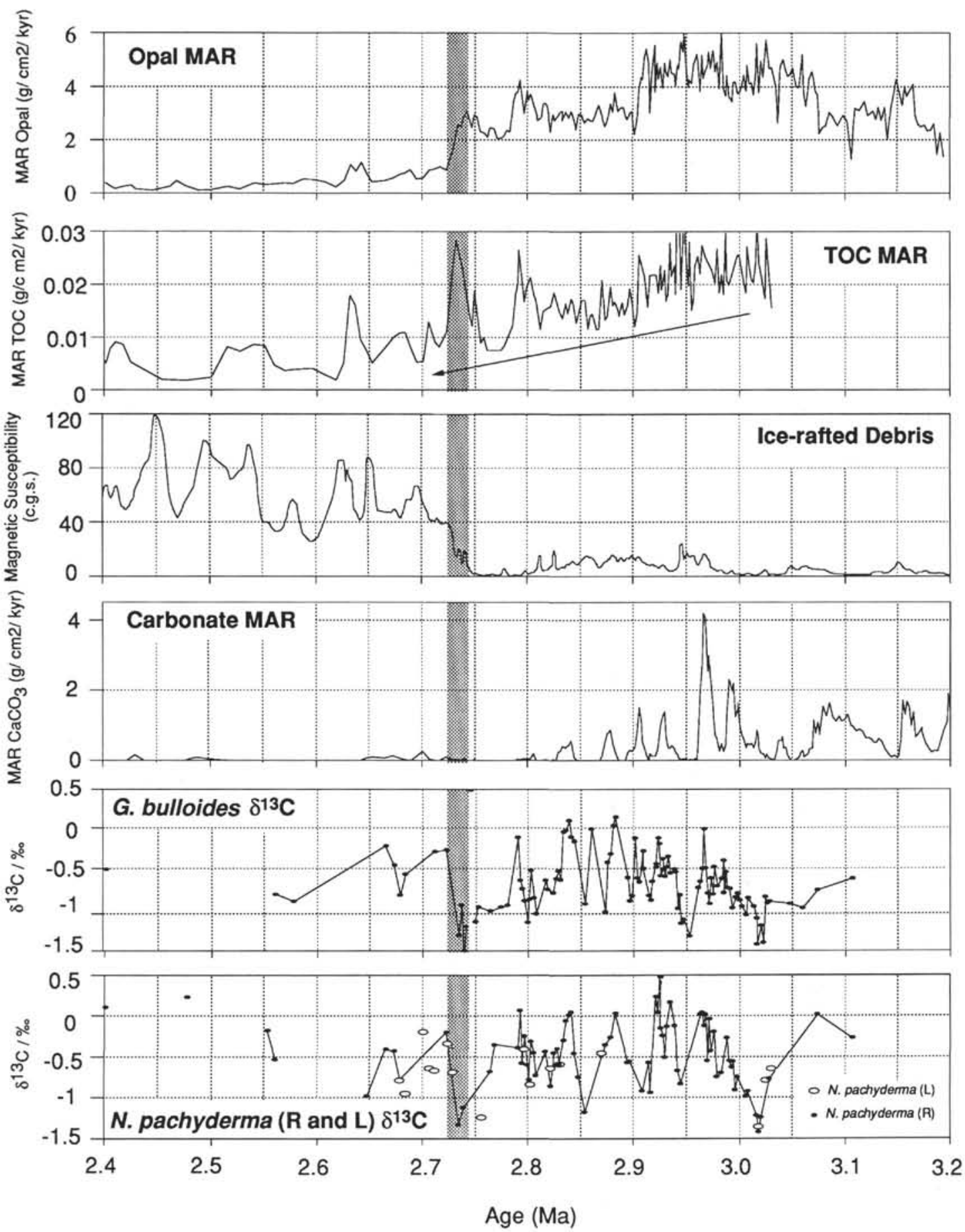

Figure 2. Comparison of biogenic opal mass accumulation rates (MARs), TOC MAR, $\mathrm{CaCO}_{3}$ MAR, and $\delta^{13} \mathrm{C}$ of $G$. bulloides and $N$. pachyderma (R and L) as proxies for surface-water paleoproductivity, and magnetic susceptibility as an indicator for terrigenous input that is primarily ice-rafted detritus at Site 882 for the time interval 2.4-3.2 Ma. The arrow indicates the longer-term decrease in the TOC MARs. The shaded region indicates the large increase in ice-rafted debris at Site 882 (magnetic susceptibility), the dramatic drop in opal MAR, and the coeval peak in TOC MAR.

in the amount of ice-rafted debris at Site 882 (Fig. 2). This dramatic increase, documented by the GRAPE density and magnetic susceptibility, is accompanied by a longer term gradual decrease in TOC MAR and a massive and irreversible drop in opal MAR. Nevertheless, coeval with this opal MAR decrease is a spike in the TOC MAR in opposition to the longer term decline (see shaded region in Fig. 2). This spike in TOC MAR may demonstrate three different environmental forcings: (1) a marked increase in surface-water productivity
(Sarnthein et al., 1992); (2) a sudden input of terrestrial organic carbon linked to the coeval discharge of ice-rafted debris; and/or (3) an exceptional short-term increase in the preservation of carbon on the seafloor as indicated by the extremely low epibenthic $C$. wuellerstorfi $\delta^{13} \mathrm{C}$ values reaching $-1.75 \%$ (Fig. 3).

This would correspond to an oxygen concentration close to zero in the deep water and sluggish circulation compared with modern standards (Michel, 1991). Note that nowhere in the modern or Last 

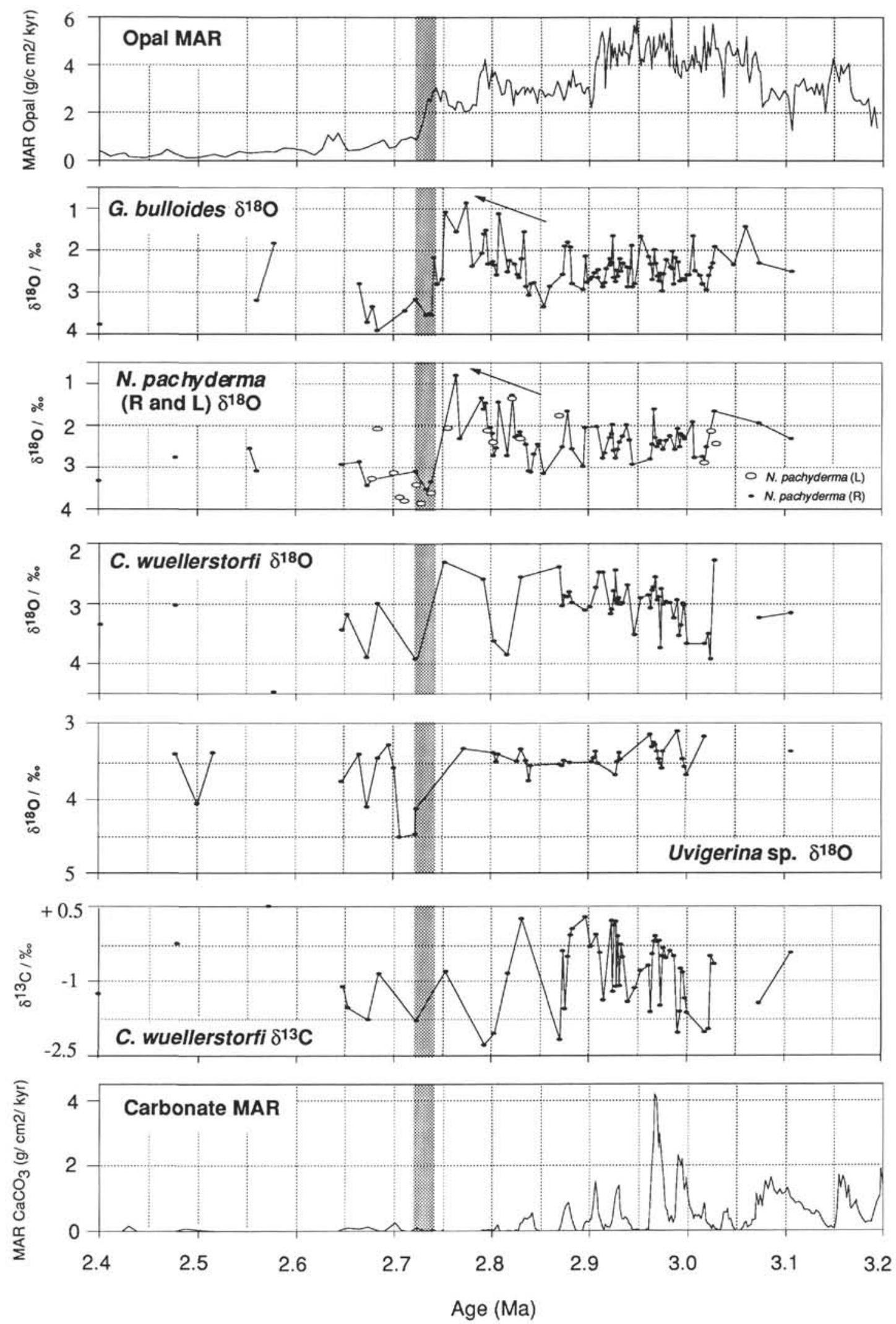

Figure 3. Comparison of biogenic opal MAR, $\delta^{18} \mathrm{O}$ of $G$. bulloides and of $N$, pachyderma ( $\mathrm{R}$ and $\mathrm{L}$ ), $\delta^{18} \mathrm{O}$ of the benthic species $C$. wuellerstorfi and $U$ vigerina sp., $\delta^{13} \mathrm{C}$ of $C$. wuellerstorfi, and $\mathrm{CaCO}_{3} \mathrm{MAR}$ at Site 882 for the time interval 2.4-3.2 Ma. The shaded region indicates the large increase in ice-rafted debris at Site 882 (magnetic susceptibility) and the dramatic drop in opal MAR. 

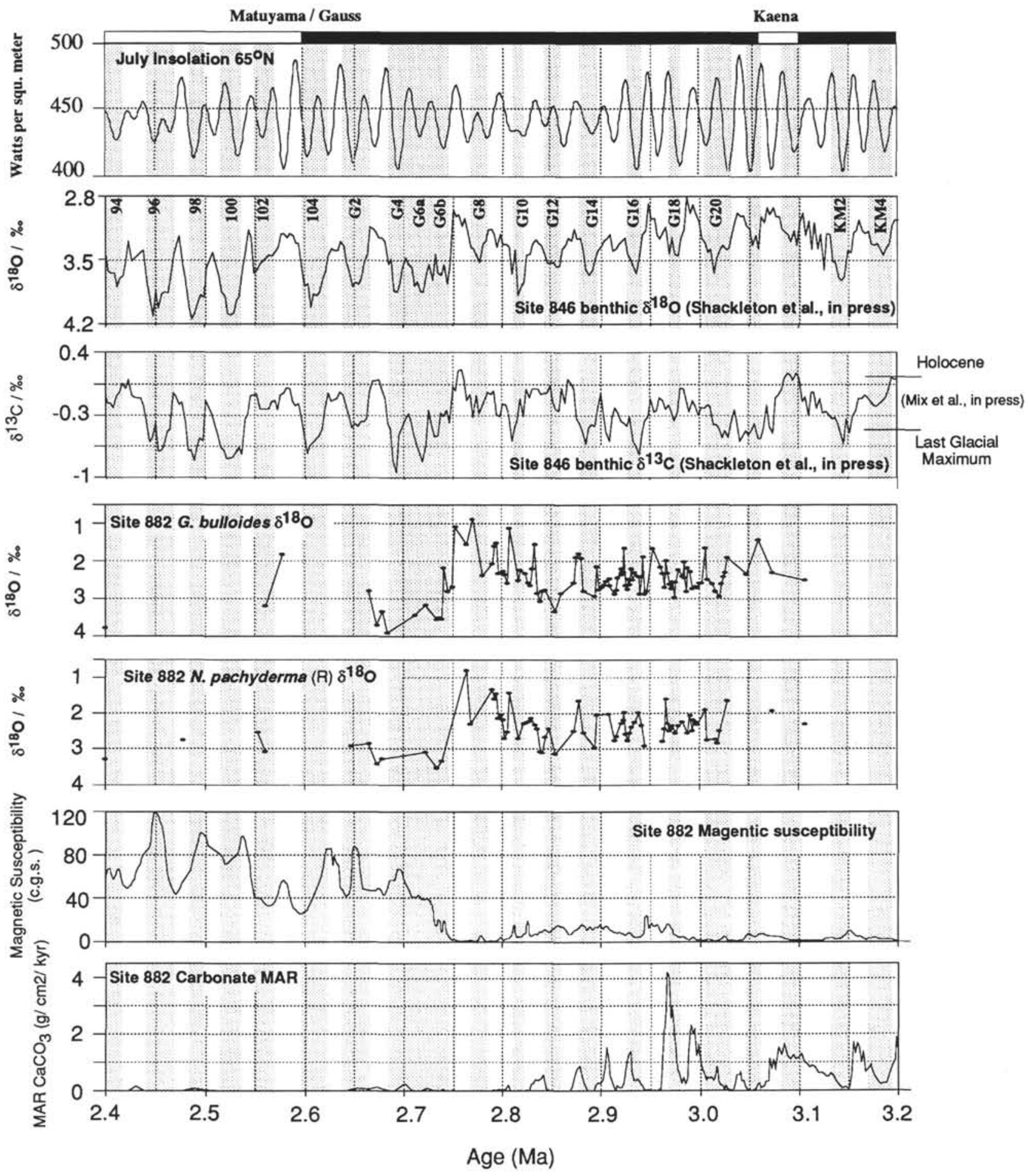

Figure 4. Comparison of the calculated insolation for $65^{\circ} \mathrm{N}$ (Berger, 1984; Berger and Loutre, 1988), benthic $\delta^{18} \mathrm{O}$ and $\delta^{13} \mathrm{C}$ isotope records from the equatorial Pacific at Site 846 (Shackleton et al., in press), the $\delta^{18} \mathrm{O}$ records from $N$. pachyderma $(\mathrm{R})$ and $G$. bulloides, and $\mathrm{CaCO}_{3} \mathrm{MAR}$ at Site 882 for the time interval $2.4-3.2 \mathrm{Ma}$. The shaded regions represent global cold periods and are labeled according to the nomenclature of Shackleton et al. (in press) and Tiedemann et al. (1994).

Glacial Maximum (LGM) oceans did epibenthic $\delta^{13} \mathrm{C}$ values decrease below $-1 \%$ (Zahn et al., 1991a); thus, the reason for these extremely light $C$. wuellerstorfi $\delta^{13} \mathrm{C}$ values is puzzling.

The strong decrease in opal MAR and the very light $\delta^{13} \mathrm{C}$ values of the all three planktonic foraminifer species measured $(-1.5 \%)$ between 2.750 and $2.725 \mathrm{Ma}$ (Fig. 2) tends to rule out suggestion 1 . Suggestion 3 may hold true to some degree, but there were very negative $C$. wuellerstorfi $\delta^{13} \mathrm{C}$ values at $2.79 \mathrm{Ma}, 3.0 \mathrm{Ma}$, and 3.04
Ma and no increase in the TOC MAR. Suggestion 2, additional organic carbon deposited by icebergs, appears to be the most important factor; additional evidence supporting this view is that the other two TOC MAR peaks at 2.63 and 2.53 approximately correlate with strong peaks in the magnetic susceptibility.

The dramatic drop in the opal MAR and the subsequent less dramatic drop in the TOC MAR are also coeval with a strong planktonic $\delta^{18} \mathrm{O}$ maximum, (i.e., much colder sea-surface temperature, 
suggesting a major reorganization of the surface-water and deepwater circulation). Various suggestions put forward to explain the North Pacific-wide drop in opal MAR are listed below and are discussed more extensively in Barron and Gladenkov (this volume), Barron (this volume), and Barron et al. (this volume).

1. The initiation of Northern Hemisphere glaciation would imply a shift in the Northern Hemisphere atmospheric circulation. An analogous case is the shift in Northern Hemisphere atmospheric circulation during the LGM due to the presence of the Laurentide ice sheet (COHMAP, 1988). The presence of ice sheets and the colder global temperatures after the major change at $2.75 \mathrm{Ma}$ would have shifted the polar front southward. This shift could have changed the surfacewater regime at Site 882 from the Kuroshio Current to the joint influence of the Oyashio Current and the Alaskan Stream (as seen today). The present circulation of the North Atlantic, which is dominated by the Gulf Stream, and is characterized by very high surface productivity primarily due to the spring blooms, may be an analog to the preglacial Pliocene North Pacific. Before $2.75 \mathrm{Ma}$, the Kuroshio Current could have flowed more northward and then eastward along the Aleutian Arc, so the Kuroshio Current could have brought nutrients to the whole North Pacific and stimulated the large surface-water productivity observed in the opal and carbonate records at all the Leg 145 Sites (Rea, Basov, Janecek, Palmer-Julson, et al., 1993). Unfortunately, today the Kuroshio (Japanese: "black water") Current is extremely nutrient poor, while the Kamchatka-Oyashio Current is more nutrient rich. Therefore, there would have to have been a complete (and therefore highly speculative) reorganization of nutrient usage in the low western equatorial Pacific for the Kuroshio to have been nutrient rich.

During the major change at $2.75 \mathrm{Ma}$, the southward movement of the polar front, the Kuroshio Current would have to flow more eastward, causing the North Pacific subpolar and Alaskan gyre seen today (Warren and Owens, 1988). The Oyashio Current and the Alaskan Stream would thus be the major surface-water influences at Site 882 , accounting for the major drop in productivity. This suggestion may be supported by the large drop in sea-surface temperatures observed in the planktonic foraminifer $\delta^{18} \mathrm{O}$ of Site 882 at $2.75 \mathrm{Ma}$.

2. A reduction in the formation of North Atlantic deep water at 2.75 Ma may have reduced the upwelling of nutrient-rich deep water in the North Pacific, and the surface-water productivity would then account for the dramatic crash in opal MAR (Haug et al., this volume). This is supported by the very negative benthic $\delta^{13} \mathrm{C}$ values at Site 882 . However, the global benthic $\delta^{13} \mathrm{C}$ records of Site 846 (Shackleton et al., in press) and 659 (Tiedemann, 1991) do not indicate any greater reduction than that seen during earlier cold periods.

3. A change in the dominant diatom species from elongated matforming to single individuals may have occurred. When a mat of diatoms sinks, the local concentration of silica is very high on the seafloor and can overcome the general corrositivity of the deep waters by sheer volume. In contrast, when single diatom tests sink they are more susceptible to dissolution; thus, a shift after $2.75 \mathrm{Ma}$ to fewer mat-forming diatoms would mean the silica rain would be more susceptible to dissolution in the deep waters. A diatom species change could have resulted from changes in the physical or chemical nature of the North Pacific surface water. At present, however, reasons for these possible species changes remain elusive, though they may be linked to the onset of Northern Hemisphere glaciation.

At present the reasons for the order of magnitude reduction of biogenic material reaching the sediment of the North Pacific, primarily due to the abrupt end of the high biogenic opal MAR which lasted at least 1 m.y., is still unresolved (Barron and Gladenkov, this volume; Barron, this volume; Barron et al., this volume). What is interesting to note is at the same time as the North Pacific underwent this dramatic reduction, the biogenic flux to the Southern Ocean increased by an order of magnitude. Hodell and Ciesielski (1990) showed that at Hole
704A in the Southern Ocean across the Gauss/Matuyama boundary $(2.6 \mathrm{Ma})$, sedimentation rates increased from $1.8 \mathrm{~cm} / \mathrm{k} . \mathrm{y}$. to $14.3 \mathrm{~cm} / \mathrm{yr}$, primarily due to a massive increase in the surface-water productivity.

\section{Comparison of Site 882 with Site 846 in the Equatorial Eastern Pacific}

The confidence in our age model between 4 and $2.4 \mathrm{Ma}$ is based first on the magnetic tie points of the Matuyama/Gauss boundary at 2.6 $\mathrm{Ma}$ and the Gauss/Gilbert at 3.6 Ma (Rea, Basov, Janecek, PalmerJulson, et al., 1993; Tiedemann et al., this volume). Secondly, both the two magnetic reversals and the low-resolution benthic $\delta^{18} \mathrm{O}$ at Site 882 suggest that GRAPE density and carbonate maxima are related to warm periods during the preglacial Pliocene, and this has facilitated the calibration of a detailed orbital tuning age model (Tiedemann and Haug, this volume).

Comparison of the planktonic $\delta^{18} \mathrm{O}$ at Site 882 with the global benthic $C$. wuellerstorfi $\delta^{18} \mathrm{O}$ and $\delta^{13} \mathrm{C}$ records of the equatorial Pacific at Site 846 (Shackleton et al., in press) indicates a high degree of similarity (Fig. 4). The most significant correlation occurs between 2.825 and $2.7 \mathrm{Ma}$ (Stages G10 to G4, using the nomenclature of Tiedemann et al., 1994). During the warm stages at 2.79 and 2.76 Ma the planktonic foraminifer $\delta^{18} \mathrm{O}$ is the highest recorded for the period 3.1 to 2.6 $\mathrm{Ma}$, indicating very high surface-water temperatures (Fig. 4). Subsequently at $2.75 \mathrm{Ma}$, coeval with the onset of the Stage G6 glaciation, significant ice rafting occurred in the North Pacific Ocean and the planktonic foraminifer $\delta^{18} \mathrm{O}$ dropped dramatically by $2.6 \%$.

If the major changes in the planktonic foraminifer $\delta^{18} \mathrm{O}$ at Site 882 between 2.85 and $2.65 \mathrm{Ma}$ are assumed to be only temperature driven (i.e., ignoring the ice volume and salinity effects), the sea-surface temperature (SST) would have increased from cold to warm periods by $6.5^{\circ} \mathrm{C}$ before $2.75 \mathrm{Ma}$ and dropped by no less than $10^{\circ} \mathrm{C}$ at 2.75 $\mathrm{Ma}$ (using the SST $-\delta^{18} \mathrm{O}$ equation of Shackleton, 1974). If the global change in ocean $\delta^{18} \mathrm{O}$, according to the benthic isotopes of Site 846, are taken into account, then this would decrease the estimated temperature change at Site 882 . If we assume that all the variation of the Site 864 benthic $\delta^{18} \mathrm{O}$ record is due to ice volume (ignoring possible deep-water cooling), the North Pacific sea-surface temperature estimates must be reduced by approximately $2.5^{\circ} \mathrm{C}(0.6 \%)$ before 2.75 $\mathrm{Ma}$ and the estimated drop at $2.75 \mathrm{Ma}$ reduced by $3.5^{\circ} \mathrm{C}(0.8 \%)$. In contrast, the possible salinity changes at Site 882 during the preglacial Pliocene are much harder to quantify. During globally cooler periods the following processes would have lowered surface-water salinity: (1) reduced upwelling of saline deep water-approximately a $0.5 \%$ to $1 \%$ reduction in salinity (Moriyasu, 1972; Craig et al., 1981); (2) increased influence of the cold Oyashio Current and thus the reduction of the influence of the warmer Kuroshio Current-approximately a $0.5 \%$ to $1 \%$ reduction in salinity (Craig et al., 1981); (3) increased precipitation (unknown effect); (4) increase in ice rafting after $2.75 \mathrm{Ma}$ (unknown effect, but ice rafting in the North Atlantic during the LGM caused a drop in salinity between $1 \%$ and $2 \%$; Duplessy et al., 1991; 1992; Maslin, 1993; Maslin et al., in press).

The following, however, would have raised surface-water salinity: (1) increase in global ice volume (between $0.1 \%$ to $0.5 \%$, which is approximately equivalent to a $10-$ to $50-\mathrm{m}$ drop in sea level [Fairbanks, 1989]); and (2) reduced evaporation because of lower sea-surface temperature (unknown effect).

If it is assumed that during a cold stage the effect of the decreased evaporation is countered by the increased precipitation, we suggest that the possible salinity changes from warm to cool periods at Site 882 could have been between $0.5 \%$ and $2 \%$. This represents a minimum oxygen isotope shift in the surface water of approximately $0.25 \%$, which increases the estimated sea-surface temperature change by at least $1^{\circ} \mathrm{C}$ (Duplessy et al., 1991; 1992; Maslin, 1993; Maslin et al., in press). In summary, considering the possible influences on the planktonic foraminifer $\delta^{18} \mathrm{O}$ record, the sea-surface temperature variation between warm and cold periods before $2.75 \mathrm{Ma}$ would have been at 
least $5^{\circ} \mathrm{C}$, whereas the sea-surface temperature drop at $2.75 \mathrm{Ma}$ was no less than $7.5^{\circ} \mathrm{C}$. This estimate could be much larger if meltwater from ice rafting was a major influence on the surface waters.

The CLIMAP Project Members $(1976,1981)$ have shown that the sea-surface temperature during the LGM, compared with the present temperature in the northwest Pacific, dropped by a fairly minor $1^{\circ}-$ $2^{\circ} \mathrm{C}$. The SST variations estimated at Site 882 for the late Pliocene are more comparable to the LGM anomalies in medium to high latitudes in other areas: for example, to the east of Japan $\left(-8^{\circ} \mathrm{C}\right)$ and at the same latitude $\left(50^{\circ} \mathrm{N}\right)$ in the North Atlantic $\left(-10^{\circ} \mathrm{C}\right.$ to $\left.-12^{\circ} \mathrm{C}\right)$. If these temperature shifts are comparable to those of the late Pliocene at Site 882 , it seems that the late Pliocene northwest Pacific was much more thermodynamic than during the last glacial-interglacial cycle. The major sea-surface temperature drop after 2.75 Ma recorded at Site 882 may support the suggestion that there could have been, at $2.75 \mathrm{Ma}$, a shift from a Kuroshio Current-dominated North Pacific to a more contemporary system with a subpolar gyre with a strong Oyashio Current and Alaskan Stream.

\section{Timing of the Initiation and Intensification of Northern Hemisphere Glaciation}

The earliest recorded onset of continental wide glaciation in Antarctica is about $35 \mathrm{Ma}$ (Shackleton et al., 1984; Ruddiman and Raymo, 1988). In contrast, it has been shown that $6 \mathrm{Ma}$ is the earliest recorded glaciation in the Northern Hemisphere (Leg 151 Scientific Party, 1994; Jansen et al., 1990; Jansen and Sjøholm, 1991). This late Miocene initiation of the Northern Hemisphere glaciation has been recorded in both the Norwegian Sea (Jansen et al., 1990; Jansen and Sjøholm, 1991) and in the Arctic (Leg 151 Scientific Party, 1994). Site 882 magnetic susceptibility records also provide evidence for late Miocene ice rafting in the northwest Pacific. A major intensification of Northern Hemisphere glaciation occurred between 3.2 and 2.5 Ma. Evidence from the Norwegian Sea suggests that the first minor increase in Arctic and possibly Scandinavian glaciation occurred at 3 $\mathrm{Ma}$, while a more pronounced and sustained increase occurred at 2.75 Ma (Jansen et al., 1990; Jansen and Sjøholm, 1991). This is supported by the magnetic susceptibility of Site 882 , which demonstrates a very minor increase at $3 \mathrm{Ma}$ (Fig. 4) and a major increase at $2.75 \mathrm{Ma}$. This confirms that there was some ice cover in the circumarctic continents beginning about $3 \mathrm{Ma}$ and significantly expanding at $2.75 \mathrm{Ma}$.

Evidence from northern Alaska (pollen, plant macrofossil, and marine vertebrate) suggests there were three major marine transgressions in the late Pliocene (Brigham-Grette and Carter, 1992; Kaufman and Brigham-Grette, 1993). These were dated using amino acid geochemistry, paleomagnetic studies, vertebrate and invertebrate paleontology, and strontium isotopes to between 2.48 and $2.7 \mathrm{Ma}$ ( 2.62 and $2.86 \mathrm{Ma}$ using the new time scale), representing three warm periods between Stages 104 and G12. They also found that these periods were too warm for permafrost and even seasonal sea ice. During the waning stages of these transgressions, the terrestrial conditions were cool enough to support an herbaceous tundra vegetation with scattered larch trees. They found no evidence for any glaciation of northern Alaska between 2.62 and $2.86 \mathrm{Ma}$, suggesting the ice rafting observed at Site 882 was predominantly from the Eurasian Arctic (via the Chukchi and Bering seas) and northeast Asia. This has been confirmed by Krissek (this volume), who has traced the major source of northwest Pacific late Pliocene ice rafting to the Kamchatka Peninsula and the northern coast of the Sea of Okhotsk.

Magnetic susceptibility and GRAPE density records from Site 887 in the Gulf of Alaska (Fig. 1) indicate a dramatic increase in the supply of ice-rafted debris (Rea, Basov, Janecek, Palmer-Julson, et al., 1993) only one obliquity cycle earlier than $2.6 \mathrm{Ma}$ (2.6 Ma is controlled by the Matuyama/Gauss boundary). This suggests that Alaska glaciated $100 \mathrm{ka}$, after the Eurasian Arctic and northeast Asia.

Evidence from DSDP Site 552 suggests that significant North American ice sheets did not occur until $2.55 \mathrm{Ma}$, when the first major pulse of ice-rafting debris is recorded in the North Atlantic Ocean (Shackleton et al., 1984). There may have been, therefore, a delay of 200 k.y. between the intensification of the glaciation of the Arctic and northeast Asia and the major ice buildup on the eastern North American continent. This suggests that the initiation and intensification of Northern Hemisphere glaciation was driven by the Arctic and North Pacific, as opposed to the Laurentide ice sheet-dominated scenario of the Last Glacial Maximum and much of the late Pleistocene (Ruddiman and McIntyre, 1981).

\section{Orbital Forcing: Possible Cause of the Initiation and Subsequent Intensification of Northern Hemisphere Glaciation}

The causes of the initiation and intensification of Northern Hemisphere glaciation remain essentially unresolved. All the major tectonic theories that have been put forward have since been refuted. The closure of the Pacific-Caribbean gateway (Keller et al., 1989) is considered too late and too gradual to have caused the major change in Pliocene climate. The Tibetan uplift (Ruddiman and Raymo, 1988) is now thought to have occurred during the late Miocene and not during the late Pliocene. While the possible emergence of the Bering Strait at 3.2 Ma (Einarsson et al., 1967; Fyles et al., 1991) may have contributed to the long-term global cooling observed in the benthic $\delta^{18} \mathrm{O}$ records (Shackleton et al., in press; Tiedemann et al., 1994), it is unlikely to be the main cause of the dramatic intensification observed at $2.75 \mathrm{Ma}$.

We suggest that the long-term cooling and the dramatic intensification of Northern Hemisphere glaciation can be explained by the changes in the orbital forcing between 4 and $2 \mathrm{Ma}$ (Fig. 5). Sediment evidence from North Atlantic Sites 607 and 609 (Ruddiman et al., 1987), tropical Atlantic Site 659 (Tiedemann et al., 1994), and equatorial Pacific Site 846 (Shackleton et al., in press) shows that the climate of the Pliocene is dominated by the 41-ka periodicity of orbital obliquity. This does not change until approximately $900-800$ $\mathrm{ka}$, when the $41-\mathrm{ka}$ cyclicity is progressively superseded by the 100 ka period of orbital eccentricity (Shackleton and Opdyke, 1973; Imbrie, 1985; Imbrie et al., 1984, 1993). Moreover, Berger et al. (1993) demonstrated that over the last $1.8 \mathrm{Ma}$ the long-term climate change can be subdivided and related to three distinct periods of orbital forcing: (1) 0-610 ka, when eccentricity-related signal is dominant; (2) $610 \mathrm{ka}$ to $1.22 \mathrm{Ma}$, when obliquity is dominant; and (3) 1.8-1.22 $\mathrm{Ma}$, when there is an equal mixture of both.

Figure 5 shows the key orbital parameters of the late Pliocene: obliquity and precession and the resultant insolation at $65^{\circ} \mathrm{N}$, as calculated by Berger (1984) and Berger and Loutre (1988). Between 4.2 and $3 \mathrm{Ma}$, orbital obliquity has relatively low amplitude variability compared with the rest of the last $6 \mathrm{Ma}$. From 3.5 to $2.5 \mathrm{Ma}$ the amplitude of the orbital obliquity gradually increases until it reaches its highest variability between 2.5 and $2.1 \mathrm{Ma}$. Such large amplitude fluctuations in orbital obliquity are only seen at approximately $5 \mathrm{Ma}$ and during the last $200 \mathrm{ka}$. If this increase is compared with the benthic foraminifer $\delta^{18} \mathrm{O}$ curve of Site 846 (an excellent record of global climate, as it records global ice volume and deep-water temperature) the $\delta^{18} \mathrm{O}$ values get gradually heavier, as observed by Tiedemann et al. (1994), paralleling the orbital obliquity (Fig. 5). Orbital obliquity has been shown to strongly affect the seasonality of the Northern Hemisphere (Ruddiman and McIntyre, 1981); thus, as the amplitude of the orbital obliquity increased from 3.5 Ma, the seasonality of the Northern Hemisphere would have correspondingly increased. Progressively colder summers promote snow and ice buildup, and once deposition achieves a critical volume, ice can survive the summers, becoming permanent and enabling expansion during following winters. This general scenario may well explain the observed gradual, though cyclic, buildup of global ice and cooling of the deep waters.

The orbital precession during the Pliocene is also important, as it modulates the amplitude of the insolation changes. The amplitude of the precession forcing during the Pliocene, unlike the obliquity, has 

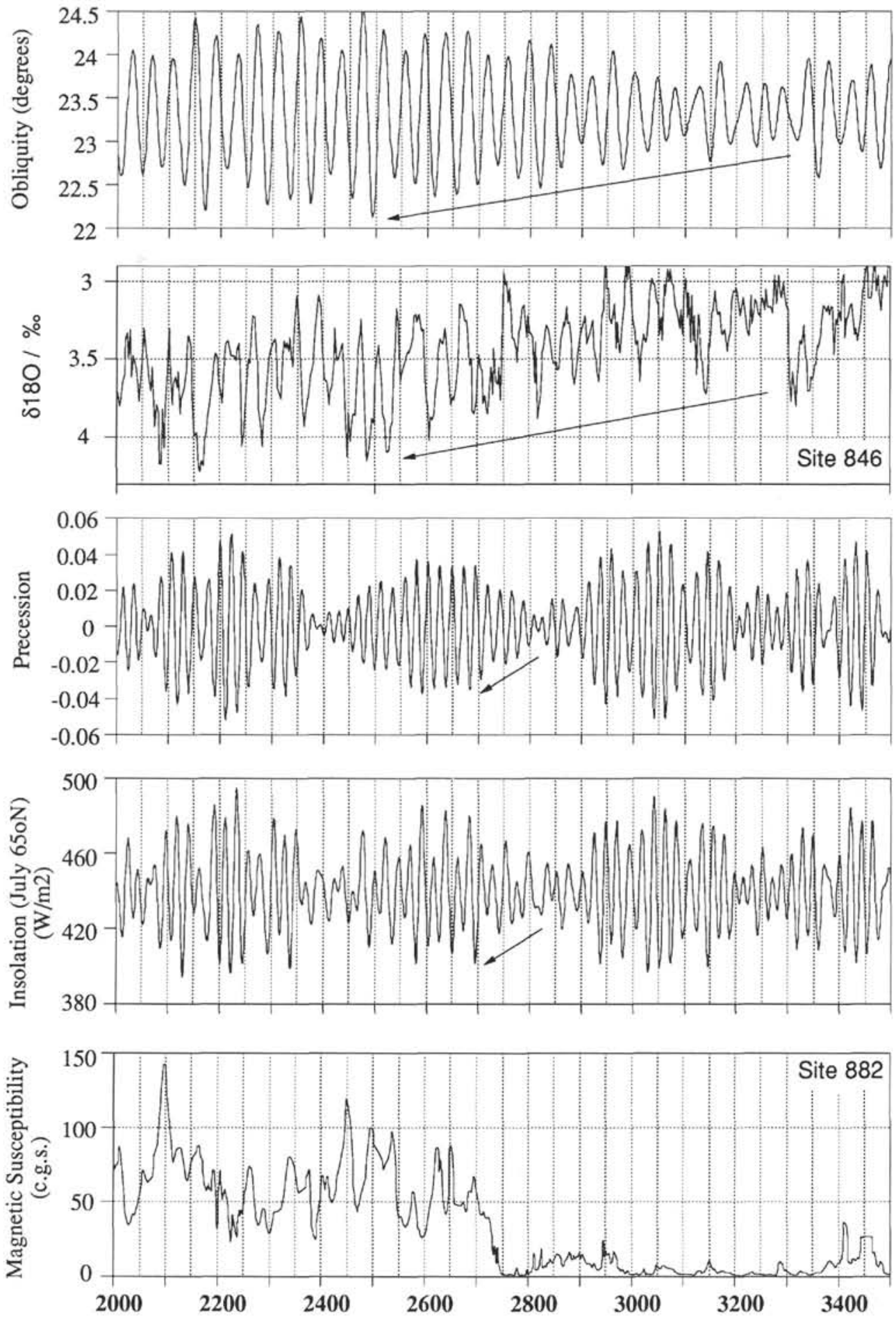

Age (ka)

Figure 5. Comparison of the key orbital parameters of the Pliocene: obliquity and precession and the resultant insolation at $65^{\circ} \mathrm{N}$, as calculated by Berger (1984) and Berger and Loutre (1988), with the benthic $\delta^{18} \mathrm{O}$ record from the equatorial Pacific at Site 846 (Shackleton et al., in press) and the magnetic susceptibility from Site 882. Arrows indicate general tends in the data. 
no long-term gradual change, but a cyclicity of approximately $400 \mathrm{ka}$. This cyclicity is also reflected in the calculated insolation (Fig. 5). Between 2.9 and $2.8 \mathrm{Ma}$ the precession signal is very low and this is reflected in the insolation. Between 2.8 and $2.7 \mathrm{Ma}$ the amplitude of the precession and consequentially the insolation increases, thus making the temperature difference between warm and cold periods much greater. This, coupled with the culmination of the gradual increase in the amplitude of obliquity we suggest, caused the buildup of largescale, permanent ice in the Arctic and northeast Asia starting at approximately $2.75 \mathrm{Ma}$.

The key factors in the intensification of Northern Hemisphere glaciation are (1) very high surface-water temperatures in the North Pacific between 2.83 and $2.75 \mathrm{Ma}$, leading to excessive evaporation and transportion of a large quantity of moisture to the North Hemisphere continents, promoting the initial glacial buildup; and (2) a subsequent sustained cold period between 2.75 and $2.685 \mathrm{Ma}$ (Stages G6a, G6b, and G4) when there was little or no climatic recovery, which records the buildup of enough permanent ice in the Northern Hemisphere to induce ice rafting at Site 882 and the Norwegian Sea and possibly affect global climate. Precession and insolation amplitudes remained large between 2.7 and $2.55 \mathrm{Ma}$, and cold periods during this period became progressively deeper (the exception being Stage 102). At $2.55 \mathrm{Ma}$ the amount of ice rafting in the Norwegian Sea (Jansen et al., 1990; Jansen and Sjøholm, 1991) and the northwest Pacific (Site 882) jumps significantly and ice rafting is first recorded in the Atlantic Ocean. At $2.55 \mathrm{Ma}$ is the first of three very intense cold periods (Stages 100-96), with the heaviest oxygen isotope values recorded up to then in the late Pliocene and the Miocene. This represents the culmination of the initiation of Northern Hemisphere glaciation with a large, permanent ice sheet on Greenland (Leg 151 Scientific Party, 1994) and a periodic ice sheet on the North American continent.

\section{CONCLUSIONS}

1. Gradual global cooling began near $3.2 \mathrm{Ma}$, which may have been influenced by an increase in the amplitude variation of orbital obliquity, increasing the seasonality of the Northern Hemisphere.

2. Minor increases in ice rafting have been detected in the Norwegian Sea and the northwest Pacific from $3 \mathrm{Ma}$.

3. A dramatic increase in ice rafting occurred in the northwest Pacific and the Norwegian Sea at $2.75 \mathrm{Ma}$, suggesting that the Eurasian Arctic and northeast Asia were significantly glaciated after 2.75 $\mathrm{Ma}$. In the northwest Pacific this major change was accompanied by a dramatic drop in sea-surface temperatures $\left(>7.5^{\circ} \mathrm{C}\right)$ and opal MARs (fivefold decrease) and was overlain by a more gradual long-term decrease in both TOC and $\mathrm{CaCO}_{3} \mathrm{MARs}$. Before this dramatic change, there was $50 \mathrm{k}$.y. of unusually warm northwest Pacific surface waters, which may have provided the moisture for ice sheet expansion before $2.75 \mathrm{Ma}$.

4. Data from Site 887 in the northeast Pacific suggest that Alaska glaciated 100 k.y. after the Eurasian Arctic and northeast Asia, while Site 552 in the Atlantic Ocean indicates Greenland and the northeast American continent glaciated 200 k.y. after the Eurasian Arctic and northeast Asia, at $2.55 \mathrm{Ma}$. Hence, the initiation and intensification of Northern Hemisphere glaciation was driven by the Arctic and North Pacific, opposed to the Laurentide ice sheet-dominated scenario of the late Pleistocene.

5. We suggest that the major intensification of Northern Hemisphere glaciation between 2.75 and $2.55 \mathrm{Ma}$ was probably forced by the culmination of the gradual increase in the amplitude of obliquity and a sharp rise in the amplitude of precession and, thus, insolation between 2.8 and $2.55 \mathrm{Ma}$.

\section{ACKNOWLEDGMENTS}

The authors are grateful to N.J. Shackleton for providing the Site 846 isotope data. We gratefully acknowledge the cooperation of $\mathrm{H}$. Cordt, who supervised the operation of the mass spectrometer in Kiel with special care. We thank E. Heinrich, J. Hennings, and I.L.U. Hohnemann for technical assistance. The Deutsche Forschungsgemeinschaft generously supported this study. We would like to thank R. Poore and an anonymous reviewer whose comments greatly improved the manuscript.

\section{REFERENCES}

Backman, J., 1979. Pliocene biostratigraphy of DSDP Sites 111 and 116 from the North Atlantic Ocean and the age of Northern Hemisphere Glaciation. Stockholm Contrib. Geol., 32:115-137.

Backman, J., and Pestiaux, P., 1987. Pliocene Discoaster abundance variations, Deep Sea Drilling Project Site 606: biochronology and paleoenvironmental implications. In Ruddiman, W.F., Kidd, R.B., Thomas, E., et al., Init. Repts. DSDP, 94 (Pt. 2): Washington (U.S. Govt. Printing Office), 903-910.

Berger, A., 1984. Accuracy and frequency stability of the Earth's orbital elements during the Quaternary. In Berger, A., Imbrie, J., Hayes, J., Kukla, G., and Saltzman, B. (Eds.), Milankovitch and Climate (Pt. 1): Dordrecht (D. Reidel), 3-39.

Berger, A., and Loutre, M.F., 1988. New insolation values for the climate of the last 10 million years. Inst. d'Astron. Geophys. G. Lemaitre, Univ. Cath. de Louvain, Louvain-la-Neuve, Belgium, Sci. Rep. 1988/13.

, 1991. Insolation values for the climate of the last 10 million years. Quat. Sci. Rev., 10:297-317.

Berger, W.H., 1989. Global maps of ocean productivity. In Berger, W.H., Smetacek, V.S., and Wefer, G. (Eds.), Productivity of the Oceans: Present and Past: New York (Wiley), 429-455.

Berger, W.H., Bickert, T., Schmidt, H., and Wefer, G., 1993. Quaternary oxygen isotope record of pelagic foraminifers: Site 806, Ontong Java Plateau. In Berger, W.H., Kroenke, L.W., Mayer, L.A., et al., Proc. ODP, Sci. Results, 130: College Station, TX (Ocean Drilling Program), 381-395.

Birchfield, G.E., Weertman, J., and Lunde, A.T., 1982. A model study of the role of high latitude topography in the climate response to orbital insolation anomalies. J. Atmos. Sci., 39: 71-87.

Bohrmann, G., Henrich, R., and Thiede, J., 1990. Miocene to Quaternary paleoceanography in the northern North Atlantic: variability in changes in carbonate and biogenic opal accumulation. In Bleil, U., and Thiede, J. (Eds.), Geological History of the Polar Oceans: Arctic versus Antarctic. Dordrecht (Kluwer), 647-675.

Bolin, B., 1950. On the influence of the earth's orography on the general character of the westerlies. Tellus, 2:184-195.

Brigham-Grette, J., and Carter, L.D., 1992. Pliocene marine transgressions of Northern Alaska: circumarctic correlation and paleoclimate interpretations. Arctic, 45:74-89.

Broecker, W.S., Andree, M., Bonani, G., Wolfli, W., Oeschger, H., Klas, M., Mix, A., and Curry, W., 1988. Preliminary estimates for the radiocarbon age of deep water in the glacial ocean. Paleoceanography, 3:659-669.

Broecker, W.S., Peteet, D.M., and Rind, D., 1985. Does the ocean-atmosphere system have more than one stable mode of operation? Nature, 315:21-26.

Charney, J.G., and Eliassen, A., 1949. A numerical method for predicting the perturbations of the middle-latitude westerlies. Tellus, 1:38-54.

CLIMAP Project Members, 1976. The surface of the ice-age Earth. Science, 191:1131-1137.

1981. Seasonal reconstructions of the Earth's surface at the last glacial maximum. Geol. Soc. Am., Map and Chart Ser., MC36.

COHMAP Members, 1988. Climatic changes of the last 18,000 years: observations and model simulations. Science, 241:1043-1052.

\footnotetext{
Abbreviations for names of organizations and publications in ODP reference lists follow the style given in Chemical Abstracts Service Source Index (published by American Chemical Society)
} 
Copeland, P., Harrison, T.M., Kidd, W.S.F., Ronghua, X., and Yuquan, Z., 1987. Rapid early Miocene acceleration of uplift in the Gangdese Belt, Xizung (southern Tibet) and its bearing on accommodation mechanisms of the India-Asia collision. Earth Planet. Sci. Lett., 86:240-252.

Craig, H., Broecker, W.S., and Spencer, D., 1981. GEOSECS Pacific Expedition (Vol. 4): Sections and Profiles: Washington (Nat. Sci. Found.)

Duplessy, J.-C., Labeyrie, L., Arnold, M., Paterne, M., Duprat, J., and van Weering, T., 1992. Changes in surface water salinity of the North Atlantic Ocean during the last deglaciation. Nature, 358:485-488.

Duplessy, J.-C., Labeyrie, L., Juillet-Leclerc, A., Maitre, F., Duprat, J., and Sarnthein, M., 1991. Surface salinity reconstruction of the North Atlantic Ocean during the last glacial maximum. Oceanol. Acta, 14:311-324.

Einarsson, T., and Albertsson, K. J., 1988. The glacial history of Iceland during the past three million years: a discussion. Phil. Trans. R. Soc. Lond. 318:637-644

Einarsson, T., Hopkins, D.M., and Doell, R.R., 1967. The stratigraphy of Tjornes, northern Iceland, and the history of the Bering Land Bridge. In Hopkins, D.M. (Ed.), The Bering Land Bridge: Stanford, CA (Stanford Univ. Press), 312-325.

Emiliani, C., and Geiss, J., 1958. On glaciation and their causes. Geol. Rundsch., 46:576-601.

Ewing, M., and Donn, W.L., 1956. A theory of ice ages. Science, 123:10611066.

Fairbanks, R.G., 1989. A 17,000-year glacio-eustatic sea level record: influence of glacial melting rates on the Younger Dryas event and deep-ocean circulation. Nature, 342:637-642.

Farrell, J.W., and Prell, W.L., 1991. Pacific $\mathrm{CaCO}_{3}$ preservation and $\delta^{18} \mathrm{O}$ since 4 Ma: paleoceanic and paleoclimatic implications. Paleoceanography. $6: 485-498$.

Flint, R.F., 1957. Glacial and Pleistocene Geology: New York (Wiley).

Fyles, J.G., Marincovich, L., Matthews, J.V., Jr., and Barrendrest, R., 1991 Unique mollusc find in the Beaufort formation (Pliocene) Meighen Island, arctic Canada. Pap.-Geol. Surv. Can., 91-B:105-112.

Harrison, T.M., Copeland, P., Kidd, W.S.F., and Yin, A., 1992. Raising Tibet. Science, 255:663-670.

Hebbeln, D., Wefer, G., and Berger, W.H., 1990. Pleistocene dissolution fluctuations from apparent depth of deposition in Core ERDC-127P, westequatorial Pacific. Mar. Geol., 92:165-176.

Hilgen, F.J., 1991. Extension of the astronomically calibrated (polarity) time scale to the Miocene/Pliocene boundary. Earth Planet. Sci. Lett., 107:349368.

Hodell, D.A., and Ciesielski, P.F., 1990. Southern ocean response to the intensification of northern hemisphere glaciation at $2.4 \mathrm{Ma}$. In Bleil, U., and Thiede, J. (Eds.), Geological History of the Polar Oceans: Arctic versus Antarctic: Dordrecht (Kluwer), 707-728.

Hodell, D.A., Müller, D.W., Ciesielski, P.F., and Mead, G.A., 1991. Synthesis of oxygen and carbon isotopic results from Site 704: implications for major climatic-geochemical transitions during the late Neogene. In Ciesielski, P.F., Kristoffersen, Y., et al., Proc. ODP, Sci. Results, 114: College Station, TX (Ocean Drilling Program), 475-480.

Hovan, S.A., Rea, D.K., and Pisias, N.G., 1991. Late Pleistocene continental climate and oceanic variability recorded in northwest Pacific sediments. Paleoceanography, 6:349-370.

Imbrie, J., 1985. A theoretical framework for the Pleistocene ice ages. J. Geol. Soc. London, 142:417-432.

Imbrie, J., Berger, A., Boyle, E., Clemens, S., Duffy, A., Howard, W., Kukla, G., Kutzbach, J., Martinson, D., McIntyre, A., Mix, A., Molfino, B., Morley, J., Peterson, L., Pisias, N., Prell, W., Raymo, M., Shackleton, N., and Toggweiler, J., 1993. On the structure and origin of major glaciation cycles, 2 . The 100,000-year cycle. Paleoceanography, 8:699-735.

Imbrie, J., Hays, J.D., Martinson, D.G., McIntyre, A., Mix, A.C., Morley, J.J., Pisias, N.G., Prell, W.L., and Shackleton, N.J., 1984. The orbital theory of Pleistocene climate: support from a revised chronology of the marine $\delta^{18} \mathrm{O}$ record. In Berger, A., Imbrie, J., Hays, J., Kukla, G., and Saltzman, B. (Eds.), Milankovitch and Climate (Pt. 1): Dordrecht (D. Reidel), 269-305.

Jansen, E., and Sjøholm, J., 1991. Reconstruction of glaciation over the past 6 Myr from ice-borne deposits in the Norwegian Sea. Nature, 349:600603.

Jansen, E., Sjøholm, J., Bleil, U., and Erichsen, J.A., 1990. Neogene and Pleistocene glaciations in the northern hemisphere and late Miocene-Pliocene global ice volume fluctuations: evidence from the Norwegian Sea. In Bleil, U., and Thiede, J. (Eds.), Geological History of the Polar Oceans: Arctic Versus Antarctic: Dordrecht (Kluwer), 677-705.
Karlin, R., Lyle, M., and Zahn, R., 1992. Carbonate variations in the Northeast Pacific during the late Quaternary. Paleoceanography, 7:43-61.

Kaufman, D., and Brigham-Grette, J., 1993. Aminostratigraphic correlations and paleotemperature implications, Pliocene-Pleistocene high-sea-level deposits, Northwestern Alaska. Quat. Sci. Rev., 12:21-33.

Keigwin, L.D., 1982. Isotopic paleoceanography of the Caribbean and East Pacific: role of Panama Uplift in late Neogene time. Science, 217:350-353. , 1978. Pliocene closing of the Isthmus of Panama, based on biostratigraphic evidence from nearby Pacific Ocean and Caribbean Sea cores. Geology, 6:630-634.

1987. Pliocene stable-isotope record of Deep Sea Drilling Project Site 606: sequential events of ${ }^{18} \mathrm{O}$ enrichment beginning at $3.1 \mathrm{Ma} . \mathrm{In}$ Ruddiman, W.F., Kidd, R.B., Thomas, E., et al., Init. Repts. DSDP, 94 (Pt. 2): Washington (U.S. Govt. Printing Office), 911-920.

Keigwin, L.D., Jones, G.A., and Froelich, N.P., 1992. A 15,000-year paleoenvironmental record from Meiji seamount, far northwestern Pacific. Earth Planet. Sci. Lett., 111:425-440.

Keller, G., Zenker, C.E., and Stone, S.M., 1989. Late Neogene history of the Pacific-Caribbean gateway. J. South Am. Earth Sci., 2:73-108.

Kennett, J.P., and Thunell, R.C., 1975. Global increase in Quaternary explosive volcanism. Science, 187:497-503.

Koblentz-Mishke, O.J., Volkovinsky, V.V., and Kabanova, J.G., 1970. Plankton primary production of the world ocean. In Wooster, W.S. (Ed.), Scientific Exploration of the South Pacific: Washington (Natl. Acad. Press), 183-193.

Leg 151 Scientific Party, 1994. Exploring arctic history through scientific drilling. Eos, 75:281-286.

Loubere, P., and Moss, K., 1986. Late Pliocene climatic change and the onset of Northern Hemisphere glaciation as recorded in the Northeast Atlantic Ocean. Geol. Soc. Am. Bull., 97:818-828.

Mann, P., and Corrigan, J., 1990. Model of late Neogene deformation in Panama. Geology, 18:558-562.

Maslin, M.A., 1993. A study of the palaeoceanography of the Northeast Atlantic in the late Pleistocene [Ph.D. thesis]. Cambridge Univ., Cambridge, U.K.

Maslin, M.A., Shackleton, N., and Pflaumann, U., in press. Surface water temperature, salinity and density changes in the N.E. Atlantic during the last 45,000 years: Heinrich events, deep water formation and climatic rebounds. Paleoceanography.

Mercier, J.-L., Armijo, R., Tapponnier, P., Carey-Gailhardis, E., and Lin, H.T., 1987. Change from late Tertiary compression to Quaternary extension in southern Tibet during the India-Asia collision. Tectonics, 6:275-304.

Michel, E., 1991. Locean ou dernier maximum glaciaire: le cycle du carbone et la circulation. Contraintes isotopiques et modelisation [Ph.D. thesis]. Univ. de Paris-Sud, Centre dOrsay, Orsay, France.

Mikolajewicz, U., Maier-Reimer, E., Crowley, T.J., and Kim, K.-Y., 1993. Effect of Drake and Panamanian gateways on the circulation of an ocean model. Paleoceanography, 8:409-426.

Mix, A.C., Le, J., and Shackleton, N.J., in press. Benthic foraminiferal stable isotope stratigraphy of Site 846: 0-1.8 Ma. In Pisias, N.G., Mayer, L.A., Janecek, T.R., Palmer-Julson, A., and van Andel, T.H. (Eds.), Proc. ODP, Sci. Results, 138: College Station, TX (Ocean Drilling Program).

Molnar, P., and England, P., 1990. Late Cenozoic uplift of mountain ranges and global climate change: chicken or egg? Nature, 346:29-34.

Moriyasu, S., 1972. Deep waters in the western North Pacific. In Stommel, H., and Yoshida, K. (Eds.), Kuroshio: Physical Aspects of the Japan Current: Seattle (Univ. Washington Press), 387-409.

Müller, G., 1967. Methods in sedimentary petrology. In Von Engelhardt, W., Füchtbauer, H., and Müller, G. (Eds.), Sedimentary Petrology (Pt. 1): Stuttgart (Schweitzerbart'sche Verlagsbuchhandlung).

North, G.R., Mengel, J.G., and Short, D.A., 1983. Simple energy balance model resolving the seasons and continents: applications to the astronomical theory of ice ages. J. Geophys. Res., 88:6576-6586.

Olausson, E., 1965. Evidence of climatic changes in north Atlantic deep sea cores, with remarks on isotopic paleotemperature analysis. Progr. Oceanogr, 3:221-252.

Opik, E., 1959. Climate and the changing sun. Sci. Am., 198:85-92.

Prell, W.L., 1984. Covariance patterns of foraminiferal $\delta^{18} \mathrm{O}$ : an evaluation of Pliocene ice volume changes near 3.2 million years ago. Science, 226:692694.

Quade, J., Cerling, T.E., and Bowman, J.R., 1989. Development of Asian monsoon revealed by marked ecological shift during the latest Miocene in northern Pakistan. Nature, 342:163-166. 
Raymo, M.E., Hodell, D., and Jansen, E., 1992. Response of deep ocean circulation to initiation of Northern Hemisphere glaciation (3-2 Ma). Paleoceanography, 7:645-672.

Raymo, M.E., Ruddiman, W.F., and Clement, B.M., 1987. Pliocene-Pleistocene paleoceanography of the North Atlantic at DSDP Site 609. In Ruddiman, W.F., Kidd, R.B., Thomas, E., et al., Init. Repts. DSDP, 94 (Pt. 2): Washington (U.S. Govt. Printing Office), 895-901.

Rea, D.K., Basov, I.A., Janecek, T.R., Palmer-Julson, A., et al., 1993. Proc. ODP, Init. Repts., 145: College Station, TX (Ocean Drilling Program).

Reid, J.L., 1965. Intermediate Waters of the Pacific Ocean: Baltimore (Johns Hopkins Press).

Ruddiman, W.F., and Kutzbach, J.E., 1991. Plateau uplift and climatic change. Sci. Am., 264:3, 66-75.

Ruddiman, W.F., and McIntyre, A., 1981. Oceanic mechanisms for amplification of the 23,000 year ice volume cycle. Science, 212:617-627.

Ruddiman, W.F., McIntyre, A., and Raymo, M., 1987. Paleo-environmental results from North Atlantic Sites 607 and 609. In Ruddiman, W.F., Kidd, R.B., Thomas, E., et al., Init. Repts. DSDP, 94 (Pt. 2): Washington (U.S. Govt. Printing Office), 855-878.

Ruddiman, W.F., Raymo, M., and McIntyre, A., 1986. Matuyama 41,000-year cycles: North Atlantic Ocean and Northern Hemisphere ice sheets. Earth Planet. Sci. Lett., 80:117-129.

Ruddiman, W.F., and Raymo, M.E., 1988. Northern hemisphere climatic regimes during the past $3 \mathrm{Ma}$ : possible tectonic connections. Philos. Trans. R. Soc. London B, 318:411-430.

Ruddiman, W., Sarnthein, M., Baldauf, J., et al., 1989. Proc. ODP, Sci. Results, 108: College Station, TX (Ocean Drilling Program).

Ruddiman, W.F., Sarnthein, M., Backman, J., Baldauf, J.G., Curry, W., Dupont, L.M., Janecek, T., Pokras, E.M., Raymo, M.E., Stabell, B., Stein, R., and Tiedemann, R., 1989. Late Miocene to Pleistocene evolution of climate in Africa and the low-latitude Atlantic: overview of Leg 108 results. In Ruddiman, W., Sarnthein, M., et al., Proc. ODP, Sci. Results, 108: College Station, TX (Ocean Drilling Program), 463-484.

Sarnthein, M., and Fenner, J., 1988. Global wind-induced change of deep-sea sediment budgets, new ocean production and $\mathrm{CO}_{2}$ reservoirs ca. 3.3-2.35 Ma BP. Philos. Trans. R. Soc. London, 318:487-504.

Sarnthein, M., Pflaumann, U., Ross, R., Tiedemann, R., and Winn, K., 1992. Transfer function to reconstruct ocean paleoproductivity: a comparison. In Summerhayes, C.P., Prell, W.L., and Emeis, K.-C. (Eds.), Upwelling Systems: Evolution Since the Early Miocene. Geol. Soc. Am. Spec. Publ., 64:411-427.

Sarnthein, M., and Tiedemann, R., 1989. Toward a high-resolution stable isotope stratigraphy of the last 3.4 million years: Sites 658 and 659 off northwest Africa. In Ruddiman, W., Sarnthein, M., et al., Proc. ODP, Sci. Results, 108: College Station, TX (Ocean Drilling Program), 167-185.

Schneider, D.A., and Kent, D.V., 1986. Influence of non-dipole field on determination of Plio-Pleistocene true polar wander. Geophys. Res. Lett., $13: 417-474$.

Shackleton, N.J., 1974. Attainment of isotopic equilibrium between ocean water and the benthonic foraminifera genus Uvigerina: isotopic changes in the ocean during the last glacial. Les Meth. Quant. d'etude Var. Clim. au Cours du Pleist., Coll. Int. C.N.R.S., 219:203-209.

Shackleton, N.J., Backman, J., Zimmerman, H., Kent, D.V., Hall, M.A., Roberts, D.G., Schnitker, D., Baldauf, J.G., Desprairies, A., Hom- righausen, R., Huddlestun, P., Keene, J.B., Kaltenback, A.J., Krumsiek, K.A.O., Morton, A.C., Murray, J.W., and Westberg-Smith, J., 1984. Oxygen isotope calibration of the onset of ice-rafting and history of glaciation in the North Atlantic region. Nature, 307:620-623.

Shackleton, N.J., Berger, A., and Peltier, W.R., 1990. An alternative astronomical calibration of the lower Pleistocene timescale based on ODP Site 677. Trans. R. Soc. Edinburgh: Earth Sci., 81:251-261.

Shackleton, N.J., Hall, M.A., and Pate, D., in press. Pliocene stable isotope stratigraphy of Site 846. In Pisias, N.G., Mayer, L.A., Janecek, T.R., Palmer-Julson, A., and van Andel, T.H. (Eds.), Proc. ODP, Sci. Results, 138: College Station, TX (Ocean Drilling Program).

Shackleton, N.J., and Opdyke, N.D., 1973. Oxygen isotope and paleomagnetic stratigraphy of equatorial Pacific core V28-238: oxygen isotope temperatures and ice volumes on a $10^{5}$ year and $10^{6}$ year scale. Quat. Res., 3:39-55.

Smagorinsky, J., 1953. The dynamical influence of large-scale heat source and sinks on the quasi-stationary mean rotations of the atmosphere. Q.J.R. Meteorol. Soc., 79:342-366.

Stommel, H., 1961. Thermohaline convection with two stable regimes of flow. Tellus, 13:224-230.

Sutcliffe, R.C., 1951. Mean upper-air contour patterns of the Northern Hemisphere-the thermal-synoptic viewpoint. Q. J. R. Meteorol. Soc., 77:435440.

Tiedemann, R., 1991. Acht Millionen Jahre Klimageschichte von Nordwest Afrika und Paleaozeanographie des Angrenzenden Atlantiks: Hochaufosende Zeitreihen von ODP Sites 658-661 [Ph.D. thesis]. Geol.Paleaont. Inst., Univ. Kiel, Ber. 46.

Tiedemann, R., Sarnthein, M., and Shackleton, N.J., 1994. Astronomical timescale for the Pliocene Atlantic $\delta^{18} \mathrm{O}$ and dust flux records of ODP Site 659. Paleoceanography, 9:619-638.

Trenberth, K.E., 1983. Interactions between orographically and thermally forced planetary waves. J. Atmos. Sci., 40:1126-1153.

Warren, B.A., and Owens, W.B., 1988. Deep currents in the Central sub-arctic Pacific Ocean. J. Phys. Oceanogr., 18:529-551.

Zahn, R., Pedersen, T.F., Bornhold, B.D., and Mix, A.C., 1991a. Water mass conversion in the glacial subarctic Pacific $\left(54^{\circ} \mathrm{N}, 148^{\circ} \mathrm{W}\right)$ : physical constraints and the benthic-planktonic stable isotope record. Paleoceanography, 6:543-560.

Zahn, R., Rushdi, A., Pisias, N.G., Bornhold, B.D., Blaise, B., and Karlin, R., 1991b. Carbonate deposition and benthic $\delta^{13} \mathrm{C}$ in the subarctic Pacific: implications for changes of the oceanic carbonate system during the past 750,000 years. Earth Planet. Sci. Lett., 103:116-132.

Zimmerman, H.B., Shackleton, N.J., Backman, J., Kent, D.V., Baldauf, J.G. Kaltenback, A.J., and Morton, A.C., 1984. History of Plio-Pleistocene climate in the northeastern Atlantic, Deep Sea Drilling Project Hole 552A. In Roberts, D.G., Schnitker, D., et al., Init. Repts. DSDP, 81: Washington (U.S. Govt. Printing Office), 861-875.

Date of initial receipt: 11 April 1994

Date of acceptance: 7 October 1994

Ms 145SR-119 
APPENDIX

Stable Isotope Data, Site 882

\begin{tabular}{|c|c|c|c|c|c|c|c|}
\hline $\begin{array}{c}\text { Composite } \\
\text { depth } \\
\text { (mbsf) }\end{array}$ & $\begin{array}{l}\text { Age } \\
\text { (ka) }\end{array}$ & $\begin{array}{c}\text { Oxygen } \\
\text { isotopes } \\
(\% \circ)\end{array}$ & $\begin{array}{c}\text { Carbon } \\
\text { isotopes } \\
(\% o)\end{array}$ & $\begin{array}{c}\text { Composite } \\
\text { depth } \\
\text { (mbsf) }\end{array}$ & $\begin{array}{l}\text { Age } \\
\text { (ka) }\end{array}$ & $\begin{array}{c}\text { Oxygen } \\
\text { isotopes } \\
(\%)\end{array}$ & $\begin{array}{c}\text { Carbon } \\
\text { isotopes } \\
(\% \circ)\end{array}$ \\
\hline \multicolumn{4}{|c|}{ Foraminifer species $C$. wuellerstorfi } & 128.20 & 2880.76 & 3.53 & -0.31 \\
\hline 96.32 & 2279.39 & 3.83 & -2.27 & 131.11 & 2903.74 & 3.52 & -0.40 \\
\hline 102.26 & 2478.17 & 3.03 & -0.24 & 131.39 & 2905.72 & 3.47 & -0.65 \\
\hline 104.73 & 2577.72 & 4.47 & 1.90 & 131.68 & 2907.46 & 3.38 & -0.79 \\
\hline 107.41 & 2647.4 & 3.43 & -1.11 & 131.97 & 2909.20 & 3.54 & -0.87 \\
\hline 107.64 & 2652.71 & 3.18 & -1.52 & 135.02 & 2927.51 & 3.69 & -0.52 \\
\hline 108.29 & 2673.51 & 3.89 & -1.77 & 135.38 & 2929.68 & 3.52 & -0.21 \\
\hline 108.87 & 2684.44 & 2.99 & -0.84 & 135.67 & 2931.42 & 3.40 & -0.88 \\
\hline 110.86 & 2722,78 & 3.92 & -1.79 & 135.97 & 2933.22 & 3.49 & -0.71 \\
\hline 117.73 & 2792.43 & 2.59 & -2.28 & 141.32 & 2963.46 & 3.15 & -0.69 \\
\hline 119.15 & 2803.09 & 3.62 & -2.05 & 141.60 & 2965.03 & 3.32 & -0.80 \\
\hline 120.91 & 2817.00 & 3.85 & -0.84 & 141.90 & 2966.71 & 3.26 & -0.58 \\
\hline 122.62 & 2831.25 & 2.56 & 0.25 & 142.19 & 2968.33 & 3.29 & -0.87 \\
\hline 127.03 & 2870.46 & 2.39 & -2.18 & 142.47 & 2969.90 & 3.38 & -0.98 \\
\hline 127.33 & 2873.22 & 3.04 & -0.39 & 142.76 & 2971.53 & 3.48 & -0.87 \\
\hline 127.56 & 2875.33 & 2.87 & -1.55 & 143.04 & 2973.10 & 3.54 & -0.92 \\
\hline 127.91 & 2878.47 & 2.89 & -0.51 & 143.33 & 2974.72 & 3.61 & -1.00 \\
\hline 128.20 & 2880.76 & 2.81 & -0.07 & 143.62 & 2976.35 & 3.38 & -1.03 \\
\hline 128.49 & 2883.05 & 2.98 & 0.05 & 146.01 & 2990.92 & 3.11 & -0.80 \\
\hline 130.24 & 2896.87 & 3.11 & 0.28 & 146.91 & 2996.64 & 3.48 & -1.06 \\
\hline 130.82 & 2901.45 & 3.05 & -0.31 & 147.15 & 2998.16 & 3.59 & -0.94 \\
\hline 131.68 & 2907.46 & 2.74 & -0.06 & 147.51 & 3000.45 & 3.69 & -1.11 \\
\hline 132.26 & 2910.94 & 2.48 & -0.43 & 150.51 & 3018.92 & 3.18 & -1.29 \\
\hline 132.84 & 2914.43 & 2.48 & -1.39 & 163.13 & 3106.71 & 3.38 & -0.73 \\
\hline 134.28 & 2923.07 & 3.17 & 0.21 & Foraminifer & s G. bullo & & \\
\hline 134.49 & 2924.33 & 3.10 & -1.21 & 96.32 & 2279.4 & 4.37 & -0.21 \\
\hline 134.79 & 2926.13 & 2.79 & 0.13 & 104.21 & 2560.7 & 3.20 & -0.80 \\
\hline 135.02 & 2927.51 & 2.95 & 0.20 & 104.73 & 2577.7 & 1.83 & -0.89 \\
\hline 135.02 & 2927.51 & 2.45 & -1.11 & 108.01 & 2665.2 & 2.80 & -0.20 \\
\hline 135.38 & 2929.68 & 3.00 & -0.10 & 108.29 & 2673.5 & 3.71 & -0.44 \\
\hline 135.67 & 2931.42 & 2.90 & -1.10 & 108.58 & 2679.0 & 3.34 & -0.81 \\
\hline 135.97 & 2933.22 & 3.01 & -0.27 & 108.82 & 2683.5 & 3.91 & -0.55 \\
\hline 136.27 & 2935.02 & 2.98 & -0.52 & 110.28 & 2711.5 & 3.44 & -0.27 \\
\hline 137.15 & 2940.08 & 2.69 & -1.42 & 110.86 & 2722.8 & 3.17 & -0.25 \\
\hline 138.35 & 2946.81 & 3.51 & $\begin{array}{r}-1.14 \\
-0.79\end{array}$ & 111.76 & 2734.3 & 3.55 & -1.31 \\
\hline 139.48 & 2953.14 & 2.90 & $\begin{array}{r}-0.79 \\
-0.69\end{array}$ & 112.06 & 2737.0 & 3.50 & -0.94 \\
\hline 140.97 & 2961.49 & 2.86 & $\begin{array}{l}-0.69 \\
-1.62\end{array}$ & 112.35 & 2739.7 & 3.54 & -1.72 \\
\hline 141.32 & 2963.46 & 3.07 & $\begin{array}{l}-1,62 \\
-0.45\end{array}$ & 112.55 & 2741.5 & 2.19 & -1.20 \\
\hline 141.60 & 2965.03 & 2.78 & $\begin{array}{l}-0.45 \\
-0.20\end{array}$ & 112.95 & 2745.1 & 2.82 & 0.51 \\
\hline 141.90 & 2966.71 & $\begin{array}{l}2.73 \\
2.56\end{array}$ & & 113.46 & 2749.8 & 2.69 & -1.14 \\
\hline 142.19 & 2968.33 & $\begin{array}{l}2.56 \\
2.94\end{array}$ & $\begin{array}{l}-0.10 \\
-0.21\end{array}$ & 113.80 & 2752.9 & 1.09 & -0.96 \\
\hline 142.47 & 2969.90 & $\begin{array}{l}2.94 \\
2.89\end{array}$ & $\begin{array}{l}-0.21 \\
-0.19\end{array}$ & 114.89 & 2764.8 & 1.56 & -1.01 \\
\hline 142.76 & 2971.53 & $\begin{array}{l}2.89 \\
3.73\end{array}$ & $\begin{array}{r}-0.19 \\
-1.49\end{array}$ & 115.79 & 2774.6 & 0.86 & -0.96 \\
\hline 143.04 & $\begin{array}{l}2973.10 \\
2974.72\end{array}$ & & -0.50 & 116.31 & 2780.3 & 2.38 & -0.94 \\
\hline 143.33 & $\begin{array}{l}2974.72 \\
2976.35\end{array}$ & $\begin{array}{l}2.75 \\
3.01\end{array}$ & -0.34 & 117.50 & 2790.7 & 2.07 & -0.10 \\
\hline 143.62 & $\begin{array}{l}2976.35 \\
2979.32\end{array}$ & $\begin{array}{l}3.01 \\
2.96\end{array}$ & -0.54 & 117.73 & 2792.4 & 1.60 & -0.63 \\
\hline 144.15 & $\begin{array}{l}2979.32 \\
2983.29\end{array}$ & 2.98 & -0.39 & 118.07 & 2795.0 & 1.52 & -0.73 \\
\hline 144.81 & $\begin{array}{l}2983.29 \\
2987.10\end{array}$ & 3.24 & -0.50 & 118.35 & 2797.1 & 2.33 & -0.88 \\
\hline 145.41 & $\begin{array}{l}2987.10 \\
2990.92\end{array}$ & 2.94 & -2.04 & 118.64 & 2799.3 & 2.32 & -1.15 \\
\hline 146.01 & $\begin{array}{l}2990.92 \\
2992.82\end{array}$ & 3.53 & -1.61 & 118.92 & 2801.4 & 2.27 & -0.86 \\
\hline 146.31 & $\begin{array}{l}2992.82 \\
2994.73\end{array}$ & 3.35 & -0.75 & 119.15 & 2803.1 & 2.36 & -0.50 \\
\hline 146.61 & $\begin{array}{l}2994.73 \\
2996.64\end{array}$ & 2.99 & -0.82 & 119.49 & 2805.6 & 2.59 & -0.85 \\
\hline 146.91 & $\begin{array}{l}2996.64 \\
2998.16\end{array}$ & 3.03 & -1.35 & 119.77 & 2807.7 & 1.13 & -1.04 \\
\hline 147.15 & $\begin{array}{l}2998.16 \\
3000.45\end{array}$ & 3.66 & -1.63 & 120.91 & 2817.0 & 2.52 & -0.63 \\
\hline 147.51 & $\begin{array}{l}3000.45 \\
3018.92\end{array}$ & 3.66 & $\begin{array}{l}-1.03 \\
-2.03\end{array}$ & 121.19 & 2819.3 & 2.25 & -0.74 \\
\hline 150.51 & 3018.92 & 3.49 & $\begin{array}{l}-1.09 \\
-1.97\end{array}$ & 121.76 & 2824.1 & 2.33 & -0.78 \\
\hline 151.11 & 3022.56 & 3.92 & -0.50 & 122.05 & 2826.5 & 2.58 & -0.61 \\
\hline 151.41 & $\begin{array}{l}3024.37 \\
3028.67\end{array}$ & 2.28 & -0.66 & 122.33 & 2828.8 & 2.66 & -0.51 \\
\hline 152.12 & $\begin{array}{l}3028.67 \\
3074.12\end{array}$ & 3.23 & -1.45 & 122.62 & 2831.2 & 2.21 & -0.62 \\
\hline 159.77 & 3074.12 & 315 & -0.43 & 122.90 & 2833.6 & 1.55 & -0.03 \\
\hline 163.13 & 3106.71 & 3.15 & -0.43 & 123.19 & 2836.0 & 2.86 & -0.01 \\
\hline Foraminifer & s Uvigeri & & & 123.52 & 2838.7 & 3.08 & 0.11 \\
\hline 102.26 & 2478.17 & 3.42 & -0.96 & 123.83 & 2841.3 & 2.80 & -0.09 \\
\hline 102.75 & 2500.90 & 4.08 & -1.30 & 124.12 & 2843.7 & 2.78 & -0.14 \\
\hline 103.05 & 2516.41 & 3.40 & -1.30 & 125.29 & 2854.5 & 3.34 & -0.92 \\
\hline 107.41 & 2647.40 & 3.78 & -0.80 & 125.87 & 2859.8 & 2.87 & 0.01 \\
\hline 108.01 & 2665.23 & 3.42 & -1.10 & 127.33 & 2873.2 & 2.58 & -1.02 \\
\hline 108.29 & 2673.51 & 4.12 & -1.22 & 127.56 & 2875.3 & 1.90 & -0.40 \\
\hline 108.87 & 2684.44 & 3.47 & -0.70 & 127.91 & 2878.5 & 1.81 & -0.30 \\
\hline 109.45 & 2695.39 & 3.29 & -0.58 & 128.20 & 2880.8 & 1.93 & 0.05 \\
\hline 109.74 & 2701.02 & 3.60 & -1.43 & 128.49 & 2883.1 & 2.80 & 0.15 \\
\hline 110.03 & 2706.66 & 4.52 & -1.03 & 129.95 & 2894.6 & 2.94 & -0.59 \\
\hline 110.86 & 2722.78 & 4.49 & -0.77 & 130.24 & 2896.9 & 2.15 & -0.88 \\
\hline 110.91 & 2723.75 & 4.15 & -0.91 & 130.47 & 2898.7 & 2.77 & -0.82 \\
\hline 115.57 & 2772.22 & 3.34 & -0.71 & 130.82 & 2901.4 & 2.70 & -0.11 \\
\hline 119.15 & 2803.09 & 3.40 & 0.30 & 131.11 & 2903.7 & 2.64 & -0.60 \\
\hline 119.49 & 2805.65 & 3.52 & -1.14 & 131.39 & 2905.7 & 2.54 & -0.65 \\
\hline 119.77 & 2807.75 & 3.42 & -1.00 & 131.97 & 2909.2 & 2.47 & -0.26 \\
\hline 122.05 & 2826.50 & 3.51 & -0.33 & 131.97 & 2909.2 & 2.66 & -0.48 \\
\hline 122.62 & 2831.25 & 3.35 & -1.39 & 132.84 & 2914.4 & 2.88 & -0.82 \\
\hline 123.19 & 2836.00 & 3.50 & -0.57 & 133.13 & 2916.2 & 2.78 & -0.87 \\
\hline 123.52 & 2838.75 & 3.77 & -0.51 & 133.41 & 2917.9 & 2.45 & -0.64 \\
\hline 123.83 & 2841.33 & 3.57 & -0.77 & 133.99 & 2921.3 & 2.21 & -0.42 \\
\hline 127.03 & 2870.46 & 3.55 & -0.19 & 133.99 & 2921.3 & 2.36 & -0.46 \\
\hline 127.33 & 2873.22 & 3.57 & -0.48 & 134.28 & 2923.1 & 2.30 & -0.11 \\
\hline 127.56 & 2875.33 & 3.50 & -0.53 & 134.49 & 2924.3 & 1.66 & -0.17 \\
\hline
\end{tabular}


APPENDIX (continued).

\begin{tabular}{|c|c|c|c|}
\hline $\begin{array}{c}\text { Composite } \\
\text { depth } \\
\text { (mbsf) }\end{array}$ & $\begin{array}{l}\text { Age } \\
\text { (ka) }\end{array}$ & $\begin{array}{c}\text { Oxygen } \\
\text { isotopes } \\
(\% o)\end{array}$ & $\begin{array}{c}\text { Carbon } \\
\text { isotopes } \\
(\%)\end{array}$ \\
\hline 134.79 & 2926.1 & 2.66 & -0.57 \\
\hline 135.02 & 2927.5 & 2.75 & -0.49 \\
\hline 135.02 & 2927.5 & 2.48 & -0.36 \\
\hline 135.38 & 2929.7 & 2.63 & -0.58 \\
\hline 135.67 & 2931.4 & 2.21 & -0.46 \\
\hline 135.97 & 2933.2 & 2.51 & -0.33 \\
\hline 136.27 & 2935.0 & 2.31 & -0.54 \\
\hline 136.87 & 2938.5 & 2.41 & -0.49 \\
\hline 137.15 & 2940.1 & 2.88 & -0.52 \\
\hline 137.46 & 2941.8 & 2.42 & -0.98 \\
\hline 137.76 & 2943.5 & 1.89 & -0.81 \\
\hline 137.99 & 2944.8 & 2.88 & -1.16 \\
\hline 138.35 & 2946.8 & 2.80 & -1.11 \\
\hline 139.48 & 2953.1 & 1.67 & -1.32 \\
\hline 140.97 & 2961.5 & 2.16 & -0.72 \\
\hline 141.32 & 2963.5 & 2.33 & -0.64 \\
\hline 141.60 & 2965.0 & 2.70 & -0.48 \\
\hline 141.90 & 2966.7 & 1.99 & 0.01 \\
\hline 142.19 & 2968.3 & 2.32 & -0.47 \\
\hline 142.47 & 2969.9 & 2.62 & -0.79 \\
\hline 142.76 & 2971.5 & 2.74 & -0.92 \\
\hline 143.04 & 2973.1 & 2.55 & -0.60 \\
\hline 143.33 & 2974.7 & 2.97 & -0.80 \\
\hline 143.62 & 2976.4 & 2.57 & -0.46 \\
\hline 144.15 & 2979.3 & 2.23 & -0.70 \\
\hline 144.81 & 2983.3 & 2.41 & -0.61 \\
\hline 145.11 & 2985.2 & 2.02 & -0.38 \\
\hline 145.11 & 2985.2 & 2.45 & -0.78 \\
\hline 145.41 & 2987.1 & 2.81 & -0.52 \\
\hline 145.65 & 2988.6 & 2.18 & -0.72 \\
\hline 146.01 & 2990.9 & 2.28 & -0.73 \\
\hline 146.31 & 2992.8 & 2.74 & -0.97 \\
\hline 146.91 & 2996.6 & 2.68 & -0.84 \\
\hline 147.15 & 2998.2 & 2.72 & -0.79 \\
\hline 147.51 & 3000.4 & 2.59 & -0.87 \\
\hline 147.81 & 3002.4 & 2.59 & -0.95 \\
\hline 148.41 & 3006.2 & 1.65 & -1.06 \\
\hline 148.65 & 3007.7 & 2.49 & -0.85 \\
\hline 149.61 & 3013.5 & 2.60 & -0.95 \\
\hline 150.15 & 3016.7 & 2.82 & -1.10 \\
\hline 150.15 & 3016.7 & 2.80 & -1.42 \\
\hline 150.81 & 3020.7 & 2.95 & -1.19 \\
\hline 151.11 & 3022.6 & 2.61 & -1.40 \\
\hline 151.41 & 3024.4 & 2.42 & -0.83 \\
\hline 151.65 & 3025.8 & 2.31 & -0.91 \\
\hline 152.12 & 3028.7 & 1.91 & -0.89 \\
\hline 155.37 & 3047.2 & 2.34 & -0.92 \\
\hline 157.42 & 3059.3 & 1.43 & -0.97 \\
\hline 159.77 & 3074.1 & 2.31 & -0.75 \\
\hline 163.13 & 3106.7 & 2.51 & -0.61 \\
\hline \multicolumn{4}{|c|}{ Foraminifer species $N$. pachyderma $(\mathrm{R})$} \\
\hline 96.32 & $2279.4^{\circ}$ & 3.83 & -0.02 \\
\hline 102.26 & 2478.2 & 2.76 & 0.23 \\
\hline 103.98 & 2553.2 & 2.54 & -0.18 \\
\hline 104.21 & 2560.7 & 3.09 & -0.54 \\
\hline 107.41 & 2647.4 & 2.92 & -0.98 \\
\hline 108.01 & 2665.2 & 2.86 & -0.41 \\
\hline 108.29 & 2673.5 & 3.43 & -0.43 \\
\hline 108.58 & 2679.0 & 3.29 & -0.78 \\
\hline 110.86 & 2722.8 & 3.10 & -0.20 \\
\hline 111.76 & 2734.3 & 3.53 & -1.33 \\
\hline 112.35 & 2739.7 & 3.35 & -1.12 \\
\hline 114.89 & 2764.8 & 0.80 & -0.68 \\
\hline 115.23 & 2768.5 & 2.31 & -0.35 \\
\hline 117.50 & 2790.7 & 1.33 & -0.39 \\
\hline 117.73 & 2792.4 & 1.60 & 0.07 \\
\hline 118.07 & 2795.0 & 1.46 & -0.58 \\
\hline 118.35 & 2797.1 & 2.15 & -0.25 \\
\hline 118.64 & 2799.3 & 2.05 & -0.60 \\
\hline 118.92 & 2801.4 & 2.18 & -0.78 \\
\hline 119.15 & 2803.1 & 2.72 & -0.31 \\
\hline 119.49 & 2805.6 & 2.53 & $-0,45$ \\
\hline 119.77 & 2807.7 & 1.43 & -0.73 \\
\hline 120.91 & 2817.0 & 2.71 & -0.44 \\
\hline 121.50 & 2821.9 & 1.27 & -0.86 \\
\hline
\end{tabular}

\begin{tabular}{|c|c|c|c|}
\hline $\begin{array}{c}\text { Composite } \\
\text { depth } \\
\text { (mbsf) }\end{array}$ & $\begin{array}{l}\text { Age } \\
\text { (ka) }\end{array}$ & $\begin{array}{c}\text { Oxygen } \\
\text { isotopes } \\
(\% o)\end{array}$ & $\begin{array}{c}\text { Carbon } \\
\text { isotopes } \\
(\%)\end{array}$ \\
\hline 121.89 & 2825.2 & 2.27 & -0.45 \\
\hline 122.24 & 2828.1 & 2.24 & -0.40 \\
\hline 122.52 & 2830.4 & 2.15 & -0.59 \\
\hline 122.90 & 2833.6 & 2.33 & -0.30 \\
\hline 123.19 & 2836.0 & 2.44 & -0.06 \\
\hline 123.52 & 2838.7 & 3.09 & 0.01 \\
\hline 123.83 & 2841.3 & 3.11 & 0.05 \\
\hline 124.12 & 2843.7 & 2.68 & -0.46 \\
\hline 124.41 & 2846.4 & 1.14 & -1.38 \\
\hline 124.64 & 2848.5 & 2.44 & -0.75 \\
\hline 125.00 & 2851.8 & 1.63 & -2.84 \\
\hline 125.29 & 2854.5 & 3.15 & -1.18 \\
\hline 125.58 & 2857.1 & 0.38 & -0.74 \\
\hline 127.33 & 2873.2 & 2.51 & -0.35 \\
\hline 127.91 & 2878.5 & 1.66 & -0.26 \\
\hline 128.49 & 2883.1 & 2.55 & 0.03 \\
\hline 129.95 & 2894.6 & 2.97 & -0.57 \\
\hline 130.24 & 2896.9 & 2.05 & -0.56 \\
\hline 131.80 & 2908.2 & 2.03 & -0.92 \\
\hline 132.84 & 2914.4 & 2.78 & -0.57 \\
\hline 133.13 & 2916.2 & 2.66 & -0.94 \\
\hline 133.99 & 2921.3 & 2.29 & 0.24 \\
\hline 134.28 & 2923.1 & 2.20 & 0.04 \\
\hline 134.49 & 2924.3 & 1.98 & 0.53 \\
\hline 134.79 & 2926.1 & 2.59 & -0.15 \\
\hline 135.02 & 2927.5 & 2.78 & -0.24 \\
\hline 135.38 & 2929.7 & 2.57 & -0.51 \\
\hline 135.67 & 2931.4 & 2.40 & -0.13 \\
\hline 136.27 & 2935.0 & 2.26 & 0.17 \\
\hline 136.87 & 2938.5 & 1.99 & -0.12 \\
\hline 137.46 & 2941.8 & 2.34 & -0.67 \\
\hline 137.99 & 2944.8 & 2.93 & -0.83 \\
\hline 141.32 & 2963.5 & 2.80 & 0.02 \\
\hline 141.60 & 2965.0 & 2.45 & 0.04 \\
\hline 141.90 & 2966.7 & 1.61 & -0.12 \\
\hline 142.19 & 2968.3 & 2.29 & 0.02 \\
\hline 142.47 & 2969.9 & 2.51 & -0.55 \\
\hline 142.76 & 2971.5 & 2.43 & -0.04 \\
\hline 143.04 & 2973.1 & 2.36 & -0.43 \\
\hline 143.62 & 2976.4 & 2.57 & -0.19 \\
\hline 144.15 & 2979.3 & 2.36 & -0.75 \\
\hline 144.81 & 2983.3 & 2.25 & -0.70 \\
\hline 145.65 & 2988.6 & 2.57 & -0.27 \\
\hline 146.01 & 2990.9 & 2.07 & -0.55 \\
\hline 146.31 & 2992.8 & 2.51 & -0.63 \\
\hline 146.61 & 2994.7 & 2.20 & -0.56 \\
\hline 146.91 & 2996.6 & 2.25 & -0.91 \\
\hline 147.15 & 2998.2 & 2.32 & -0.75 \\
\hline 148.41 & 3006.2 & 1.91 & -0.99 \\
\hline 148.65 & 3007.7 & 2.76 & -0.92 \\
\hline 150.15 & 3016.7 & 2.74 & -1.22 \\
\hline 150.51 & 3018.9 & 2.85 & -1.42 \\
\hline 150.81 & 3020.7 & 2.51 & -1.24 \\
\hline 152.12 & 3028.7 & 1.66 & -0.77 \\
\hline 159.77 & 3074.1 & 1.94 & 0.02 \\
\hline 163.13 & 3106.7 & 2.31 & -0.27 \\
\hline \multicolumn{4}{|c|}{ Foraminifer species $N$. pachyderma $(\mathrm{L})$} \\
\hline 108.58 & 2678.98 & 3.27 & -0.79 \\
\hline 108.87 & 2684.44 & 2.08 & -0.95 \\
\hline 109.74 & 2701.02 & 3.14 & -0.20 \\
\hline 110.03 & 2706.66 & 3.71 & -0.64 \\
\hline 110.32 & 2712.29 & 3.80 & -0.67 \\
\hline 110.91 & 2723.75 & 3.42 & -0.34 \\
\hline 111.20 & 2729.18 & 3.86 & -0.69 \\
\hline 112.35 & 2739.68 & 3.62 & -1.66 \\
\hline 114.08 & 2755.95 & 2.06 & -1.24 \\
\hline 118.35 & 2797.09 & 2.12 & -0.41 \\
\hline 119.15 & 2803.09 & 2.40 & -0.84 \\
\hline 121.50 & 2821.92 & 1.34 & -0.64 \\
\hline 122.52 & 2830.42 & 2.31 & -0.59 \\
\hline 127.03 & 2870.46 & 1.77 & -0.46 \\
\hline 150.51 & 3018.92 & 2.89 & -1.36 \\
\hline 151.65 & 3025.82 & 2.14 & -0.79 \\
\hline 152.51 & 3030.96 & 2.43 & -0.65 \\
\hline
\end{tabular}

